\title{
Procedimentos estruturais na obra Titanium de João Pedro Oliveira ${ }^{1}$
}

\author{
Levy Oliveira (Universidade Federal de Minas Gerais, Belo Horizonte, MG, Brasil) \\ pacheco.levy@gmail.com
}

\author{
João Pedro Oliveira (Universidade Federal de Minas Gerais, Belo Horizonte, MG, Brasil) \\ jppo@ua.pt
}

\begin{abstract}
Resumo: Este trabalho visa analisar os aspectos estruturantes da peça Titanium (para piano a 4 mãos, 2 pianos de brinquedo e eletrônica), do compositor português João Pedro Oliveira. Para tal, 3 aspectos foram estudados com maior relevância: Processos de desenvolvimento motívico, articulação da estrutura formal e exploração tímbrica. Os modelos e procedimentos encontrados a partir desta análise proporcionam um maior entendimento do pensamento do compositor e servirão de embasamento para futuros trabalhos.

Palavras-chave: Titanium (para piano a 4 mãos, 2 pianos de brinquedo e eletrônica); Análise estrutural; Exploração timbríca.
\end{abstract}

Structural procedures in João Pedro Oliveira's piece Titanium

Abstract: This paper aims to analyze structural aspects of the piece Titanium (for piano 4-hands, 2 toy pianos and electronics) of Portuguese composer João Pedro Oliveira. Three main aspects will be addressed in this analysis: motivic development, articulation of the global form and timbric exploration. The compositional models and procedures found in the analysis of this piece will help to achieve a better understanding of the composer's thinking and will be used as basis for future works.

Keywords: Titanium (for piano 4-hands, 2 toy pianos and electronics); Structural analysis; Timbric exploration.

Procedimientos estructurales en la obra Titanium de João Pedro Oliveira

Resumen: En este trabajo se pretende analizar aspectos estructurales en la pieza Titanium (piano a 4 manos, 2 pianos de juguete y sonidos electrónicos) del compositor portugués João Pedro Oliveira. Con este fin, se estudiaron tres aspectos de mayor relevancia: los procesos de desarrollo de elementos musicales, la articulación de la estructura formal, y la exploración tímbrica. Los modelos y procedimientos que se encuentran a partir de este análisis proporcionan una mayor comprensión de las ideas del compositor y servirán como base para trabajos futuros.

Palabras clave: Titanium (piano a 4 manos, 2 pianos de juguete y sonidos electrónicos); análisis estructural; exploración de timbres.

\section{Introdução}

Titanium², composta em 2014, foi escrita sob encomenda para o "Duo CardAssiS” (formado pelas pianistas Luciane Cardassi e Ana Cláudia Assis). A obra é para piano a quatro mãos, dois pianos de brinquedo e eletrônica. Através deste trabalho, busca-se entender o processo criativo do compositor, bem como os aspectos importantes na linguagem musical desta obra. Acredita-se ser de grande importância o entendimento da música feita atualmente, para que o trabalho do compositor (estudante ou profissional) não se torne obsoleto no seu próprio tempo. O estudo analítico aqui apresentado, será importante para o desenvolvimento do trabalho de composição dos autores do artigo, uma vez que os métodos analisados serão utilizados na construção de novas obras.

Para isso, será dado enfoque na análise de alguns aspectos. Começando pelo pensamento harmônico e pelo desenvolvimento motívico, seguiremos na análise da articulação e delimitação da estrutura formal; por último, será feita uma abordagem sobre a importância do timbre no desenvolvimento e na articulação da forma global da peça. 
Seguindo o modelo proposto por Gubernikoff (2008, p. 33), a análise realizada buscou um estudo direto sobre a obra musical, sem a aplicação de uma metodologia “sem objeto”. Sendo assim, não foi nosso intuito a aplicação de uma metodologia específica. A análise foi realizada a partir da música e, só então, se considerou quais metodologias seriam mais adequadas para explicar as questões analisadas. Para isso, as principais referências utilizadas para a elaboração desse estudo foram a partitura e a escuta, visando extrair da obra suas características. A escolha desse método se deve a dois propósitos principais: construir uma abordagem da técnica composicional utilizada em Titanium e explicitá-la de forma que seja assimilável pelo ouvinte, excluindo aspectos metafísicos ou extramusicais, tendo sempre em mente a adequação ao pensamento musical de João Pedro Oliveira, no qual a utilização de sistemas não é uma prioridade. De acordo com o próprio compositor (2010):

Sistema e sistematização são tomados como ‘sugestões’ de trabalho e nunca como re-
gulamentos. Se em obras como os Integrais ${ }^{3}$ já se verifica uma certa liberdade na utili-
zação de procedimentos sistemáticos, nas composições mais recentes (...), o tratamen-
to sistemático é reduzido muitas vezes a operações muito simples que são utilizadas
e combinadas sem qualquer esquema prévio. (p. 134)

Percebe-se certo pensamento composicional intuitivo, que tem adquirido um papel cada vez mais importante no processo de escrita de João Pedro Oliveira. Tal pensamento é assumido pelo compositor como sendo influência direta da sua experiência com a música eletrônica. Ao compor música acusmática, o compositor se vê diante de um procedimento distinto daquele encontrado na escrita de uma partitura. Durante o trabalho de organização dos sons, o compositor tem acesso instantâneo ao resultado sonoro do que foi composto, cedendo assim uma importância especial à escuta analítica e autocrítica. Segundo Oliveira (2010), esse procedimento tem sido transposto também à escrita de sua música para instrumentos:

A forma de compor tem sido cada vez mais influenciada pelo pensamento de laboratório, que é habitualmente usado na música eletrônica. Esse pensamento baseia-se na dialéctica da escuta - avaliação - consolidação. O que foi composto ontem é avaliado hoje e consolidado em conjunto com o que for composto amanhã. (p. 134)

Sendo sua linguagem musical não baseada na sua essência em um sistema rígido, torna-se mais interessante uma análise guiada pela audição com apoio da partitura. Uma análise deste tipo, levando em consideração as consequências sonoras das decisões de João Pedro Oliveira, pretende evitar a descoberta de padrões falsos e/ou sem interesse real na partitura e na escuta.

\section{O pensamento harmônico e o desenvolvimento motívico}

O pensamento harmônico de Titanium é baseado na criação de hierarquias entre intervalos musicais. É facilmente perceptível já nos primeiros compassos da obra (Figura 1 - excerto áudio 1$)^{4}$ a importância que adquire o intervalo de quinta justa e segunda menor, representados no primeiro gesto do piano de brinquedo 2, pelos intervalos Dó-Sol e Sol-Fá\# e, mais a frente, no compasso 3, pelos intervalos Dó-Sol e Dó-Réb realizados pelo pianista 1. 


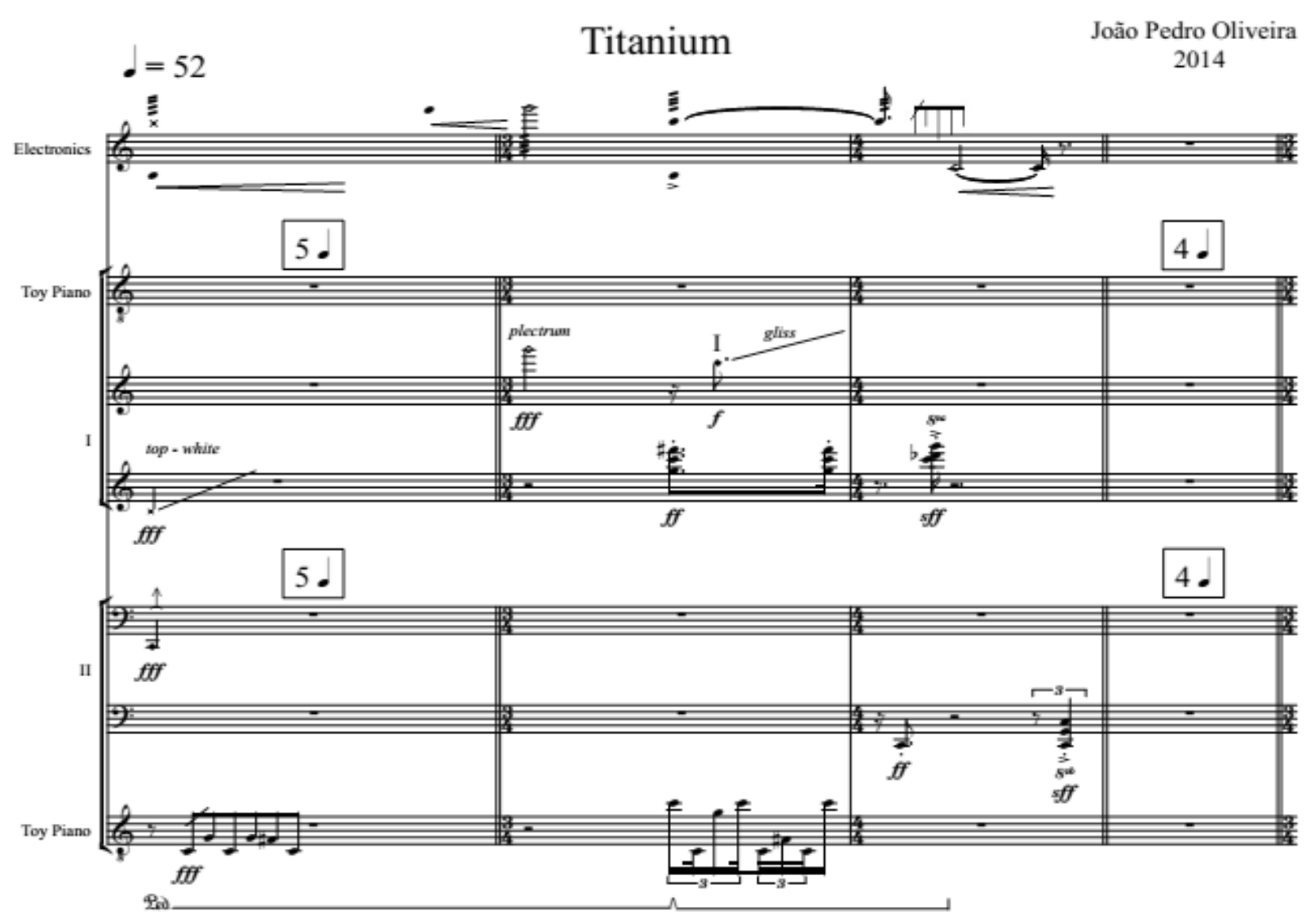

Figura 1: C 1-4 de Titanium

Fonte: OLIVEIRA, 2014.

Na Figura 2, uma redução intervalar desta passagem enfatiza essas relações. As construções intervalares baseadas nesses intervalos serão consideradas - fazendo um paralelo à tradição tonal - como uma tônica. Aplicando o mesmo princípio da hierarquização de intervalos a outras formações intervalares distintas, como veremos mais adiante, o compositor constrói elementos harmônicos que permitem criar a ideia musical de tensão/relaxamento.

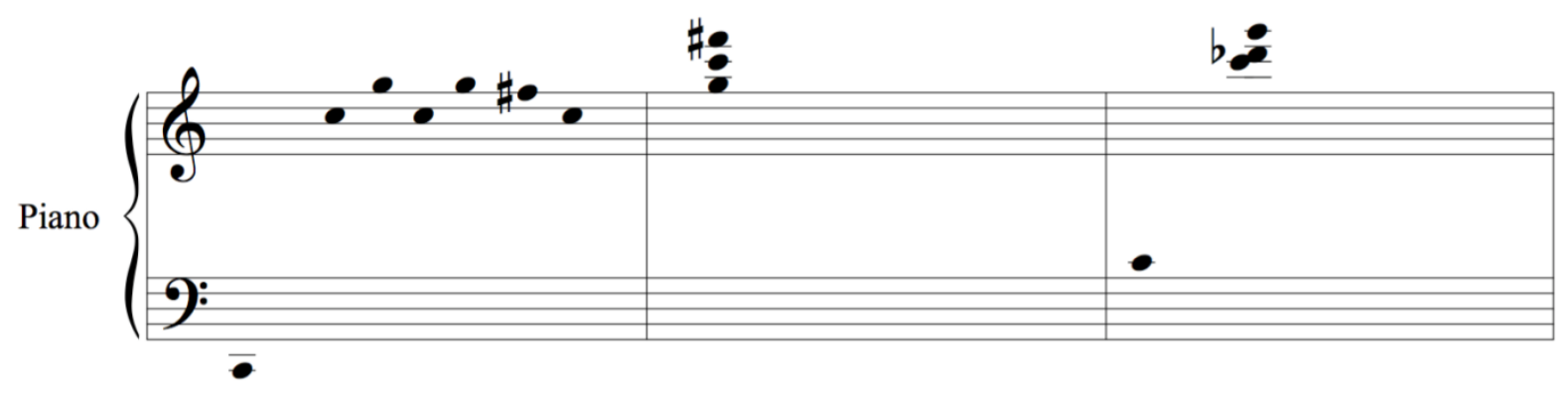

Figura 2 - Redução intervalar dos c. 1-3

Fonte: OLIVEIRA, 2017.

Este tipo de manipulação intervalar é confirmado pelo próprio compositor no seu texto, não publicado, intitulado "Sistema, Intuição e Tempo: Por uma Identidade Composicional”. Segundo João Pedro Oliveira (2010): 


\begin{abstract}
A nossa proposta encaminhou-se nos últimos 12 anos cada vez mais progressivamente para uma 'tonicização' do intervalo, sendo a cadência perfeita, típica da tonalidade, substituída pela relação mais simples que é possível encontrar na estrutura intervalar de cada composição. Simultaneamente, se numa obra tonal as relações estruturais estão sempre dependentes da oposição da tonalidade principal com outras tonalidades secundárias, e posterior retorno a essa tonalidade, no nosso pensamento, essa oposição e retorno é precisamente feita com a utilização de intervalos diferentes dentro da obra. (p. 31).
\end{abstract}

A criação de tensão baseada na organização intervalar torna-se clara no aproximar do ponto climático da peça (compassos 90-91) (Figura 3 - excerto áudio 2). Neste momento, o motivo inicial baseado no arpejo do "intervalo-tônica" (Figura 1 - compasso 1 no piano de brinquedo do pianista II) se torna mais denso e reaparece, mas agora, como repetição de um mesmo acorde (Figura 3 - pauta superior do pianista I). Como se pode perceber, ainda aparece um arpejo do intervalo de quinta justa na pauta superior do pianista II - o que é essencial para manter a coerência harmônica -, entretanto, os acordes repetidos são fundamentados no intervalo de segunda e sétima que enfatizam e auxiliam a criação da tensão, ao contrário do intervalo de quinta justa que traria repouso harmônico à textura.

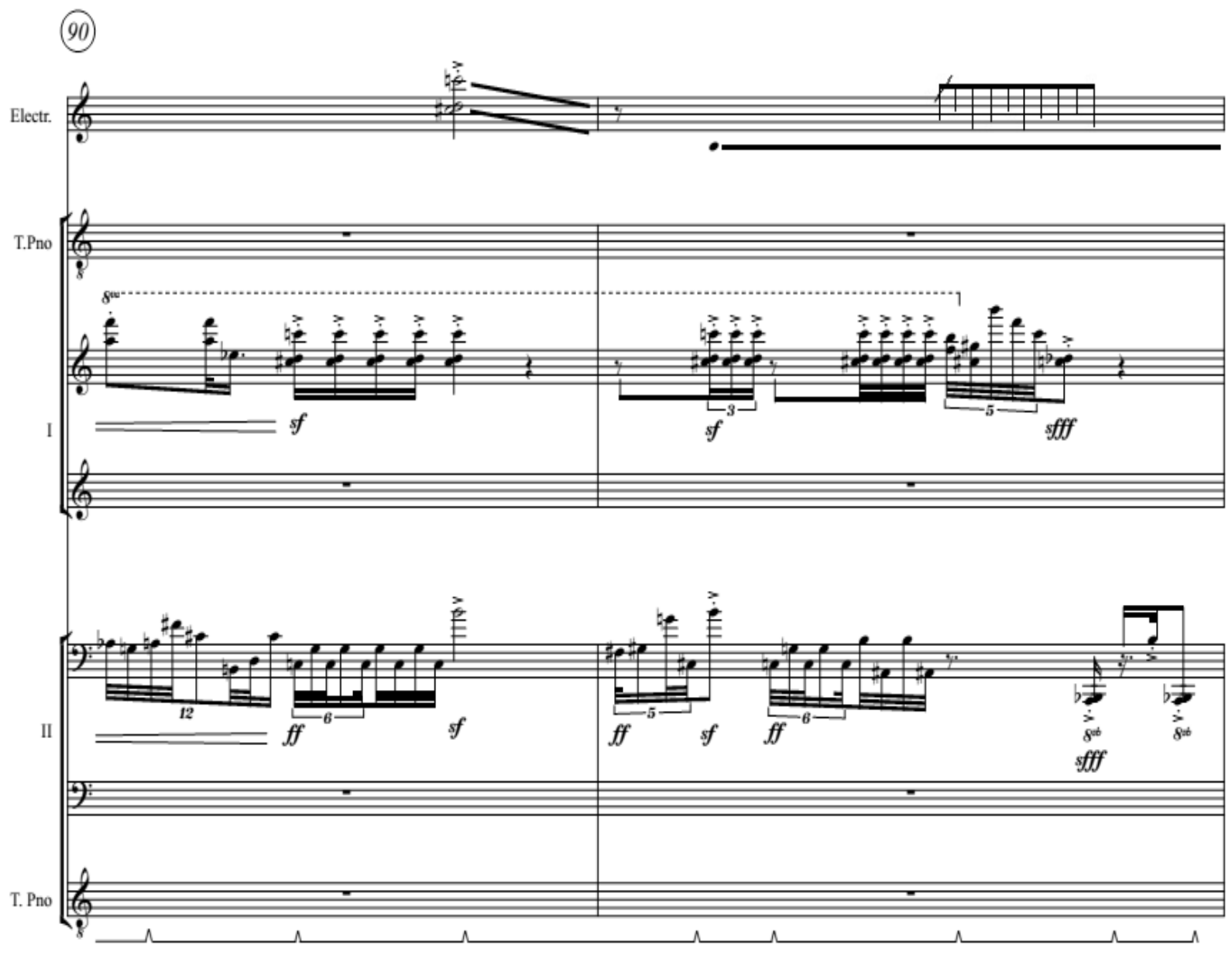

Figura 3 - C. 90-91 de Titanium

Fonte: OLIVEIRA, 2017. 
seia.

Na Figura 4, apresentamos a hierarquia de intervalos na qual essa passagem se ba-

\section{Hierarquia I}

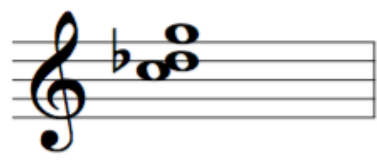

Intervalo-Tônica: Responsável pela sensação de repouso

\section{Hierarquia II}

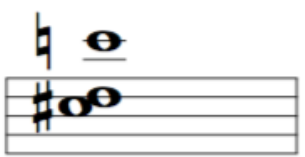

Intervalos-Dissonantes: Responsáveis pela criação de tensão.

Figura 4 - Hierarquias intervalares

Fonte: OLIVEIRA, 2017.

As alternâncias entre tais hierarquias são recorrentes em toda a peça. Apesar da distinção dos conteúdos intervalares, os intervalos-dissonantes são variações do intervalo-tônica. No exemplo da Figura 4, o intervalo de semitom é mantido, porém, o intervalo de quinta é substituído pelo de sétima maior. Essa nova formação contribui para o aumento da tensão inerente a essa construção intervalar e, ao mesmo tempo, mantém a coerência do discurso harmônico.

O equilíbrio entre essas duas hierarquias permite o controle do acúmulo de tensão neste momento que é de grande importância no percurso formal da obra ${ }^{5}$. Além disso, podemos também observar que esta construção harmônica deriva diretamente dos primeiros compassos da peça, analisados anteriormente.

Novamente, essas ideias podem ser confirmadas pelas palavras do próprio compositor, quando ele fala da estruturação harmônica utilizada na composição do seu ciclo Integrais. De acordo com Oliveira (2010, p. 39):

O método melódico-harmónico utilizado no ciclo Integrais provou ser bastante útil na tarefa de atingir os objetivos propostos [...]. Construir uma estrutura sistemática 'formatadora' das relações harmônicas da obra, contribuindo assim para a sua coerência composicional. Mais ainda, a diferença entre os intervalos usados em cada composição permite facilmente alcançar sonoridades harmônicas bem distintas entre si.

Em Titanium, ao contrário do ciclo Integrais, sonoridades distintas são criadas em uma única obra e utilizadas como fator estrutural, mostrando o desenvolvimento da linguagem composicional de João Pedro Oliveira nos quase 30 anos que separam a criação destas peças. Sendo assim, a estruturação harmônica traz fortes reflexos na organização estrutural.

Outra característica importante na obra do compositor é o pensamento composicional influenciado pela teoria dos fractais e pela noção de autosemelhança em diferentes níveis da obra. Segundo Oliveira (2010, p. 43), "A ideia do todo refletido nas partes e vice-versa, tem sido constante nas nossas preocupações conceptuais sobre o aspecto da forma”. Na Figura 1, pode-se perceber o desenvolvimento sutil do motivo inicial no piano de brinquedo II. A harmonia é a mesma nos compassos 1 e 2, entretanto possui uma maior amplitude de registro e também uma organização rítmica mais complexa no compasso 2.

Outro exemplo interessante da variação do motivo inicial da obra ocorre no compasso 50, que corresponde, como se verá adiante, ao início da segunda seção da peça (Figu- 
ra 5 - excerto musical 3), sugerindo novamente uma relação de ampliação motívica, na qual as frases musicais mais complexas derivam de uma exploração interna dos motivos iniciais da obra.

Neste momento, entra em campo outro interesse científico do compositor, que se relaciona com a teoria da lógica difusa. Diferente da lógica clássica, a lógica difusa permite o alcance de conclusões aproximadas, sendo que o resultado, apesar de refletir características específicas das operações de transformação realizadas ou das estruturas que foram modificadas, não possui necessariamente uma exatidão computável ${ }^{6}$. Ao transpor essa ideia à música, Oliveira (2010) afirma:

O nosso interesse em relação à lógica difusa partiu das possibilidades de "fractalização" de um percurso entre dois pontos do espaço, tomando como premissas que o início e o fim do mesmo seriam determinados, mas o percurso intermédio poderá ter diversas versões. (p. 59)

No excerto representado pela Figura 5 (compassos 48 a 55), este conceito parece-nos evidente. Enquanto o pianista I começa com um gesto idêntico ao realizado pelo piano de brinquedo II no segundo compasso da peça (Figura 1), o pianista II realiza variações sobre essa ideia. A harmonia ainda é, majoritariamente, a mesma. Entretanto, há uma mudança interessante. João Pedro Oliveira utiliza um processo semelhante ao de multiplicação, proposto por Boulez (KOBLYAKOV, 1993), usando como referência os intervalos de base da obra. Nesse exemplo (Figura 5), na harmonia inicial, baseada no acorde Dó, Fá\#, Sol, é mapeada uma segunda menor acima, transformando-se em Réb-Sol-Láb no piano de brinquedo II. Assim sendo, nesse momento, a microestrutura da obra interfere na macroestrutura, auxiliando na criação de tensão. Pelo fato de, no início da obra, a imagem criada ser de uma harmonia estável, baseada apenas numa segunda menor e numa quinta justa, neste excerto, a sobreposição da mesma harmonia com a sua transposição uma segunda menor superior, cria um choque de dissonâncias que desestabiliza a relação inicial. Esta tensão se resolve ao retornar à harmonia inicial (arpejo de Dó-Sol) no fim do compasso 50. Esse exemplo mostra um processo de variação com um ponto de partida e de chegada específicos que abrem diferentes alternativas no caminho a ser percorrido.

Um exemplo mais complexo da utilização da lógica difusa em Titanium ocorre ainda neste mesmo excerto. O gesto realizado pelo pianista I na terceira semínima do compasso 50 (começando em Dó-Sib-Ré) é utilizado como apoio básico, sendo ele tanto ponto de partida quanto ponto de chegada da ideia musical. Após esta ideia ter sido interrompida no final do compasso 50, é retomada no compasso seguinte pelo mesmo pianista, desta vez sendo desintegrada ritmicamente nos pianos de brinquedo, e no compasso 55 é transferida integralmente para o piano de brinquedo II. É também interessante mencionar a forma como é feita a manipulação tímbrica: enquanto a ideia musical gira em torno dos mesmos motivos e harmonias, o timbre gera a ideia de movimento, pois começa no piano e é progressivamente transferida para o piano de brinquedo. Tal característica será discutida de forma mais aprofundada na seção 4 deste artigo. 
(50)
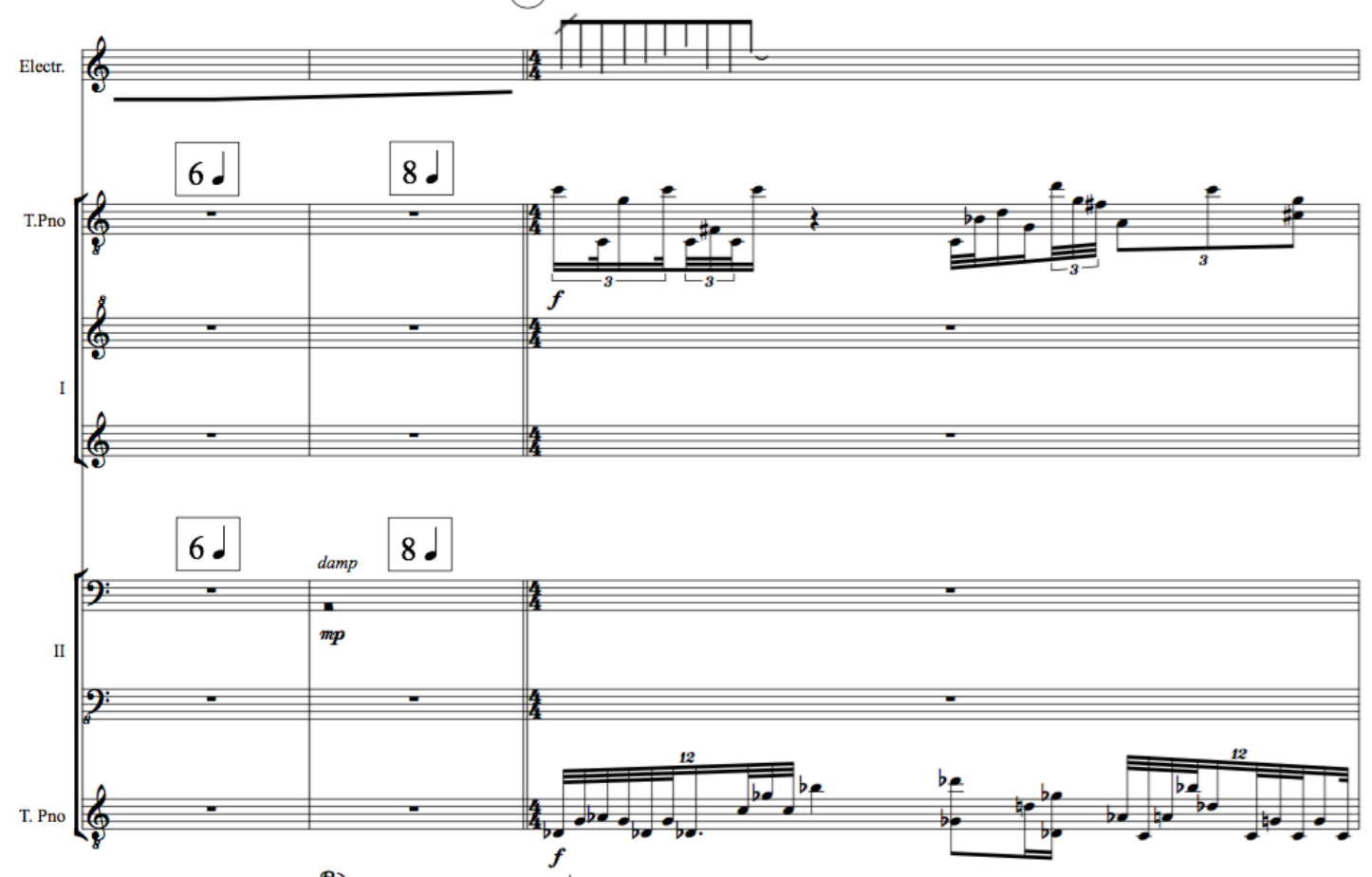

Ted

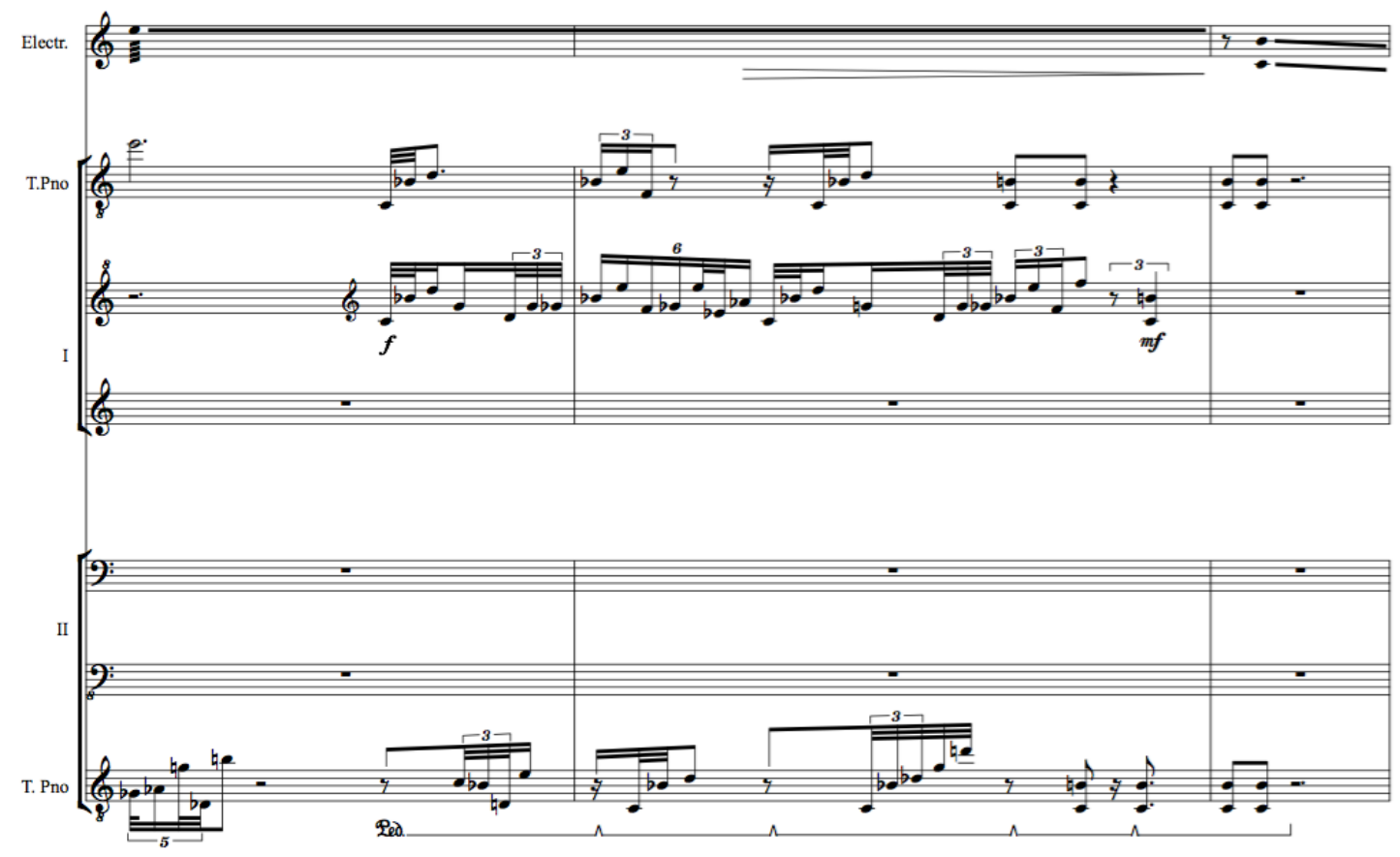


12

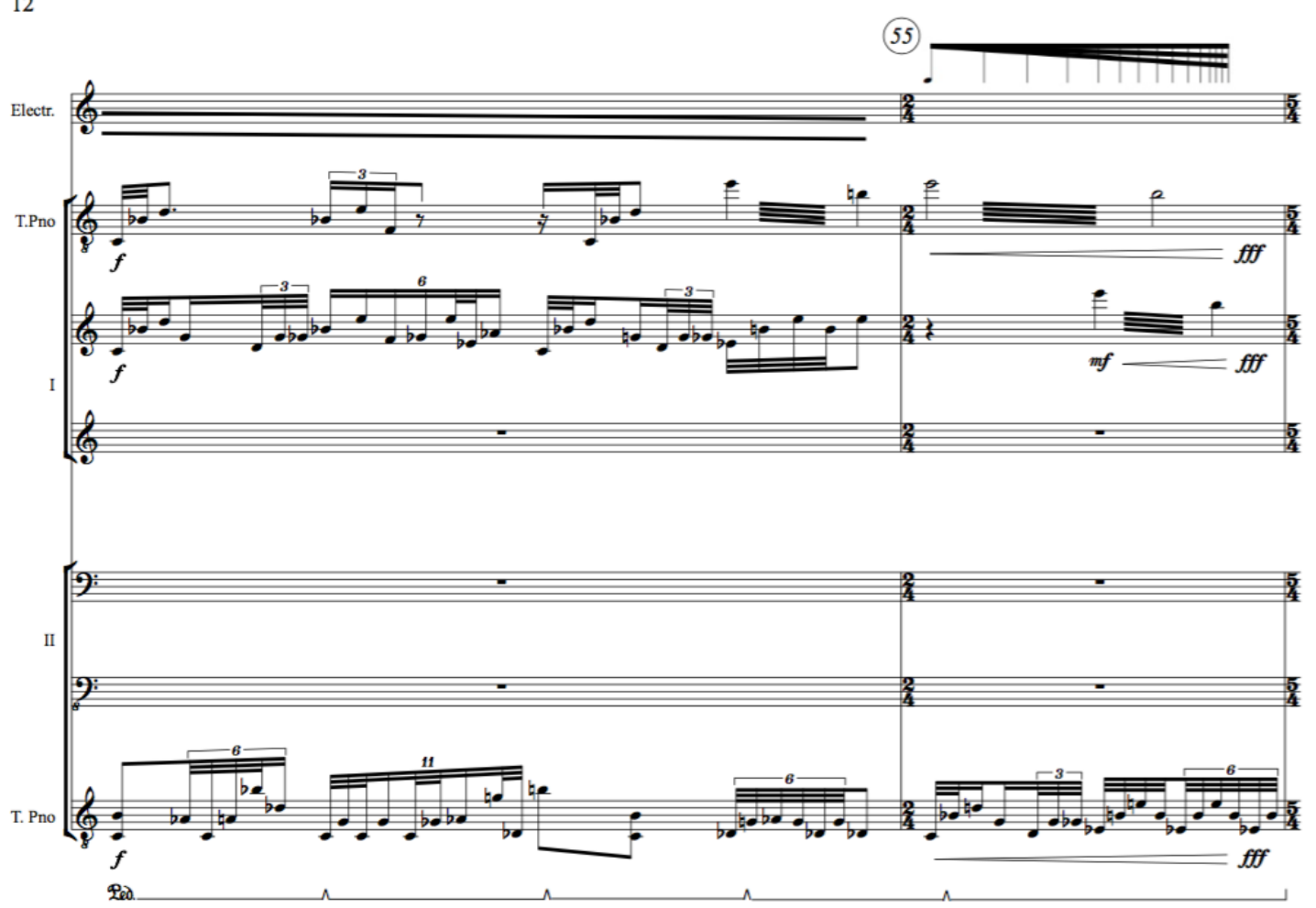

Figura 5 - c. 48-50 de Titanium

Fonte: OLIVEIRA, 2014.

Tais manipulações motívicas são de grande importância estrutural, pois são elas que, ao criarem pequenas variações do material inicial, desenvolvem o discurso musical, permitindo gerar diferentes níveis de tensão ou repouso musical. Desta forma, o compositor interfere com as expectativas do ouvinte, sugerindo, apresentando, escamoteando e surpreendendo. A importância deste tipo de procedimento composicional que leva em consideração um processo de variância/invariância é também tratada por McAdams e Saariaho. Segundo eles (1985):

Relações entre diferentes categorias devem ser capazes de manter um certo grau de invariância sob vários números de classes de transformações. Se padrões de transformações são compostos dentro de um conjunto de dimensões que não são suscetíveis a serem percebidos como similares, então o conjunto não pode contribuir fortemente para a forma musical. (p. 368)

A partir das variações e transformações descritas acima, que são exploradas em quase toda a obra, Titanium pretende adquirir uma forma coerente, tanto no ponto de vista harmônico quanto motívico. Desta forma, cria-se um discurso baseado numa ideia com o potencial para se desenvolver em múltiplas direções, mas que, mesmo assim, permite que o ouvinte relacione auditivamente diferentes seções da obra. Tal procedimento também auxilia com o potencial de conclusão ou encerramento cadencial, outro aspecto importante que possibilita o controle sobre as articulações do discurso musical dentro desta obra.

No transcorrer da peça, o "intervalo tônica" é retomado com grande enfoque em diversos momentos, sendo que, em todos eles, é retratada uma articulação formal importante dentro da estrutura da obra. Estes momentos são de grande valor para a compreensão das ideias de Titanium, principalmente ao agregar as interferências do timbre neste processo. 
Esses aspectos serão discutidos na próxima seção do texto.

\section{Articulações da estrutura formal de Titanium}

Devido à forma de organização do material musical, após a escuta da peça, é possível perceber com alguma clareza suas seções. Titanium possui duas grandes seções: seção A (compassos 1-50) e seção A' (compassos 77-117), sendo que a seção A' carrega consigo diversas semelhanças com a seção A. Estas duas seções são entrepostas por duas seções menores: seção B (compassos 50-77) e seção C (compassos 117-144), que funciona como uma coda. A Figura 6 apresenta um gráfico geral da estrutura de Titanium, onde são igualmente incluídas outras subseções importantes da peça. A partir desta definição, buscou-se entender quais recursos foram dispostos pelo compositor para alcançar esta estrutura. Uma análise mais detalhada dos diversos momentos de articulação entre seções (compassos 25, 50, 70, 77, 97, 107, 117 e 144) permitiu-nos entender como se processou a construção da estrutura formal.

McAdams e Saariaho (1985, p. 367) definem seis critérios ${ }^{7}$ para investigar o potencial de demarcação formal de um material específico. Segundo os autores, a memória tem uma função importante nesse processo. Sendo assim, quanto mais marcante é um elemento musical, maiores serão as chances de este ser um grande delineador formal. Entende-se então, que a distribuição desses delineadores formais no discurso musical terá grande relevância devido às suas fortes características articuladoras. A partir desse entendimento, buscou-se compreender quais seriam esses elementos de estruturação formal em Titanium.

A -

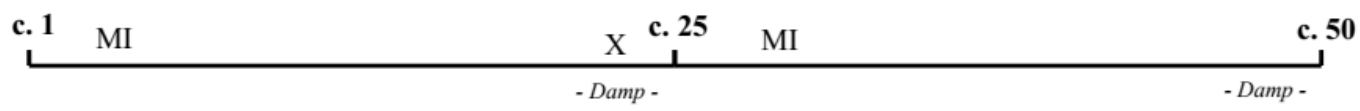

B -
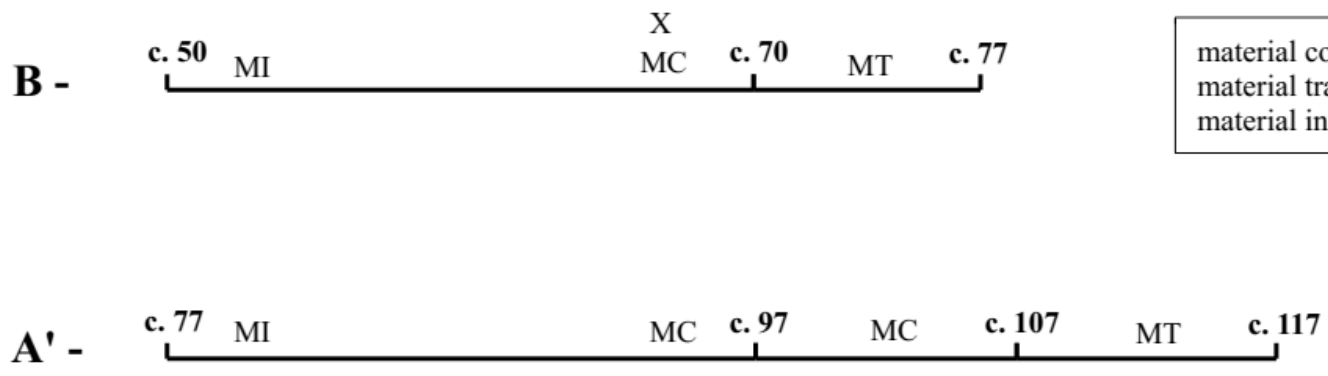

C -

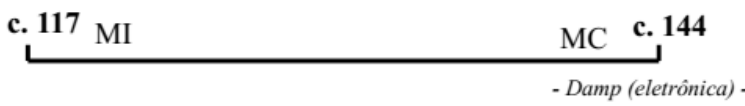

Figura 6 - Esquema formal de Titanium

Fonte: OLIVEIRA, 2017. 
Como já discutido, um importante elemento na concepção estrutural da obra é a tonicização dos intervalos de quinta justa e segunda menor. A peça inicia-se com essa "tônica”, e ela está claramente presente em outros pontos do discurso musical. Nos compassos 64 a 69 (Figura 7 - excerto áudio 4), a harmonia baseia-se quase exclusivamente nesse material, reaparecendo também nos compassos 94 a 107 e, posteriormente, no compasso 134 ao $144^{8}$. Ao analisar essas informações à luz do gráfico da Figura 6, pode-se perceber que esse material sempre se encontra finalizando importantes pontos de articulação formal. Sendo assim, esse material recebeu o nome de material conclusivo (MC).

Nesses regressos à tônica, existe uma grande e contínua ênfase da harmonia nos intervalos de base da obra (segunda menor e quinta justa). Anteriormente a esses momentos, as várias manipulações das hierarquias intervalares (expostas na Figura 4) estão dispostas de forma a gerarem tensão. Desta forma, quando ocorrem os retornos aos intervalos de base da obra, a noção de relaxamento é ainda maior. Sendo assim, pode-se afirmar que o caráter conclusivo da harmonia presente em MC é otimizado. Como afirmado por McAdams e Saariaho (1985, p. 368), o compositor criou, a partir da organização dos elementos musicais, funções de relaxamento e tensão com materiais específicos, enfatizando a importância da disposição hierárquica dos intervalos.

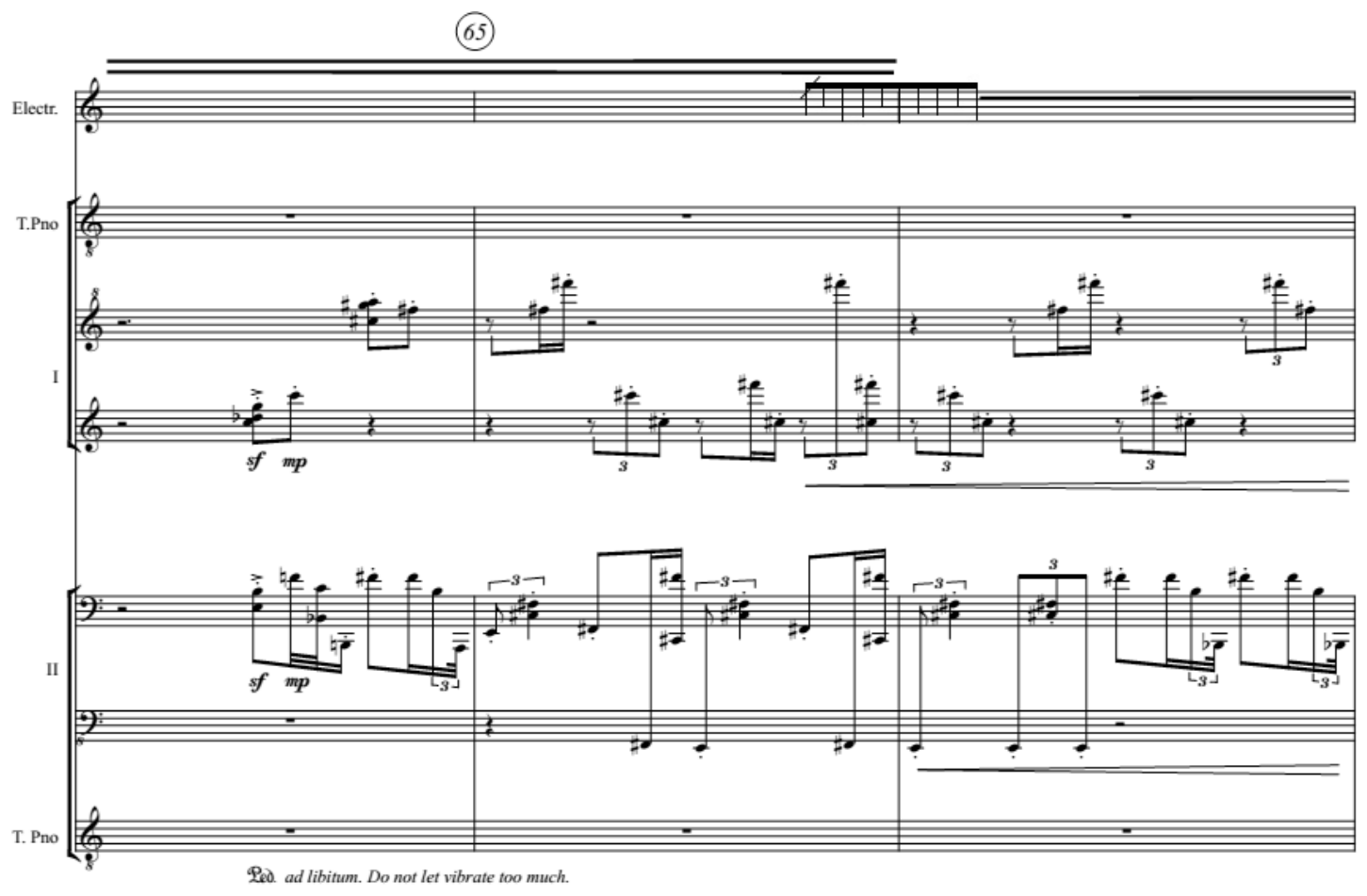

Figura 7 - C. 64-66 de Titanium

Fonte: OLIVEIRA, 2014.

Vale ressaltar que, além de uma harmonia própria, outro fator que oferece maior identidade ao MC é a textura rítmica desta passagem, pois essa característica deixa o soar do material ainda mais marcante, auxiliando na sua memorização pelo ouvinte e, como já discutido, esse aspecto aumenta as chances de um material musical ser percebido como um articulador formal. Além disso, nesses materiais conclusivos, a textura estável - devido à utilização do intervalo de oitava, e a utilização de uma heterofonia articulada sempre sobre as mesmas notas e mesmo registro - ajuda no processo de conclusão.

Após as aparições desses materiais conclusivos nas seções $B$ e $C$, outro material 
importante surge na estruturação da peça. Esse material foi nomeado material de transição (MT) e está presente nos compassos 70 a 77 (Figura 8 - excerto áudio 5) e 107 a 117. Aí encontra-se um desenvolvimento de uma ideia que foi ouvida pela primeira vez no compasso inicial da obra, consistindo num gesto musical em que é utilizada uma palheta (ou qualquer outro dispositivo de plástico duro) friccionada nas teclas do piano para produzir um som similar ao de um reco-reco. Durante esses compassos, além do som do reco-reco, os pianistas fazem glissandos nas cordas do piano, impondo uma forte caracterização a essas passagens e atribuindo-lhes uma função formal. Neste caso, como se pode ver no gráfico da Figura 6 , esse material sempre aparece com ênfase após uma conclusão, levando assim a novas seções, daí a sua interpretação analítica como material de transição.

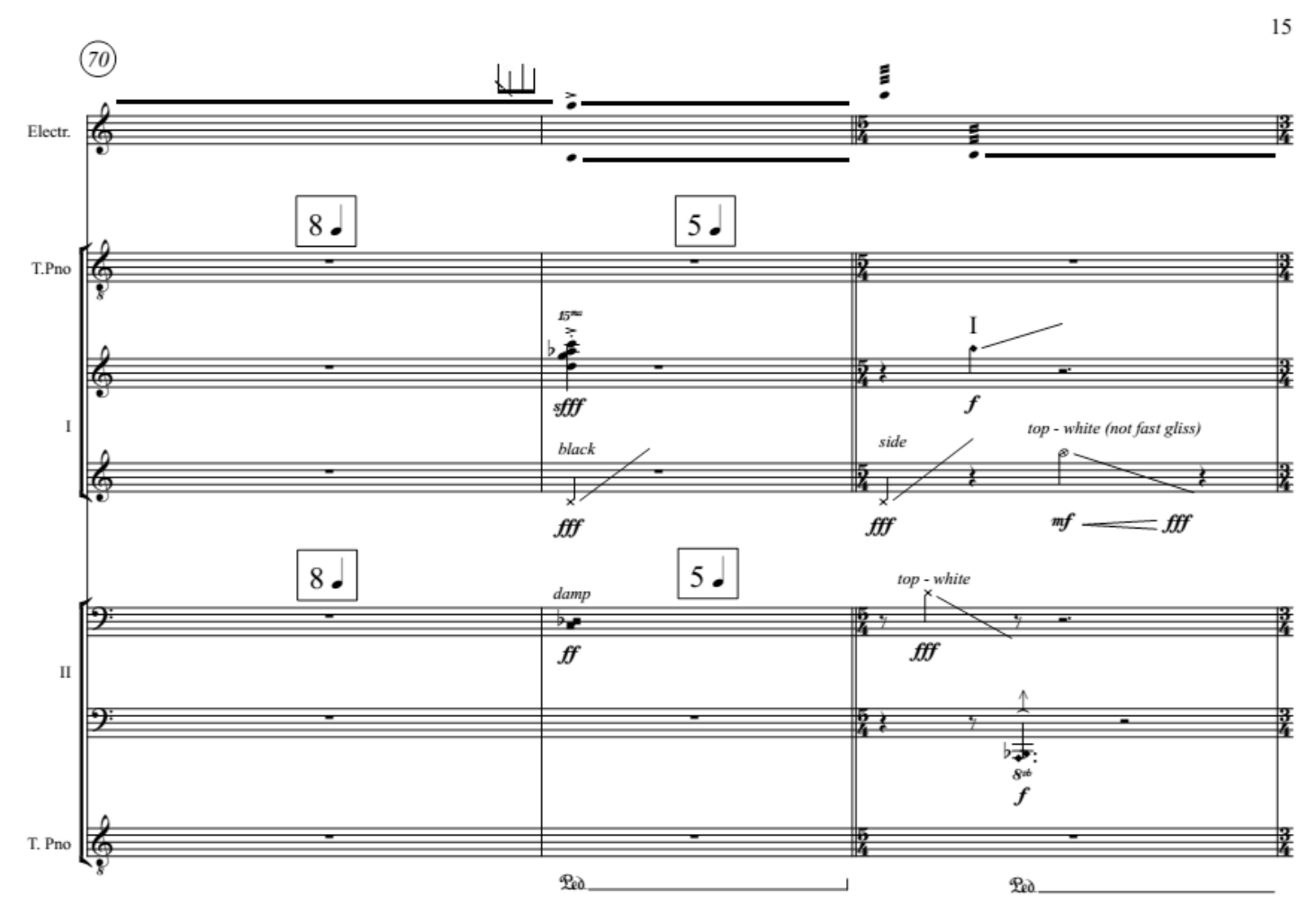

Figura 8 - C. 70-72 de Titanium

Fonte: OLIVEIRA, 2014.

Este mesmo material (som de reco-reco), ao ser analisado levando em consideração a microestrutura da obra, apresentará também diferentes funções. Entre estas, podemos mencionar a ampliação tímbrica do piano e aprimoramento da interação entre instrumento acústico e eletrônica. Estes pontos serão abordados com mais aprofundamento na próxima seção deste texto.

Como já afirmado, para McAdams e Saariaho (1985, p. 367), a forma como os materiais estão organizados em uma música são essenciais para a criação de relações entre eles, fazendo com que seja possível entender analítica e perceptualmente suas funções em um determinado contexto. Essa ideia é exemplificada pelos autores através do papel do acorde de sétima dominante na música tonal, sendo que sua função é distinta, dependendo se encadeado com a tônica ou com o sexto grau. Da mesma forma, quando João Pedro Oliveira utiliza duas vezes o material conclusivo seguido pelo material de transição, ele fortalece a relação de terminação e condução a novas seções, confirmando assim, as funções que são destinadas a estes materiais. 
Em Titanium, se encontram ainda dois materiais musicais, intrinsecamente ligados ao timbre, que são importantes e influenciam diretamente na estrutura da obra: o damping do piano (Figura 9 - excerto áudio 6), e o gesto em direção ao agudo realizado pela eletrônica logo no começo da peça (Figura 1 - excerto áudio 1).

O damping é recorrente em pontos articulatórios conclusivos. Na Figura 9 - excerto áudio 6, correspondente aos compassos 23-25 -, a eletrônica reverbera o gesto realizado pelos pianistas no último tempo do compasso 22. Após este breve momento de suspensão criado pela eletrônica, o pianista II ataca a nota Si em damp (compasso 24), conduzindo ao fim a primeira subseção de A. Além disso, como pode se ver nas demarcações realizadas na Figura 6, o damp também conclui a segunda subseção de $A$, e também, apesar de executado pela eletrônica ${ }^{9}$, recebe a importante função de ser o último som da obra, no compasso 144.
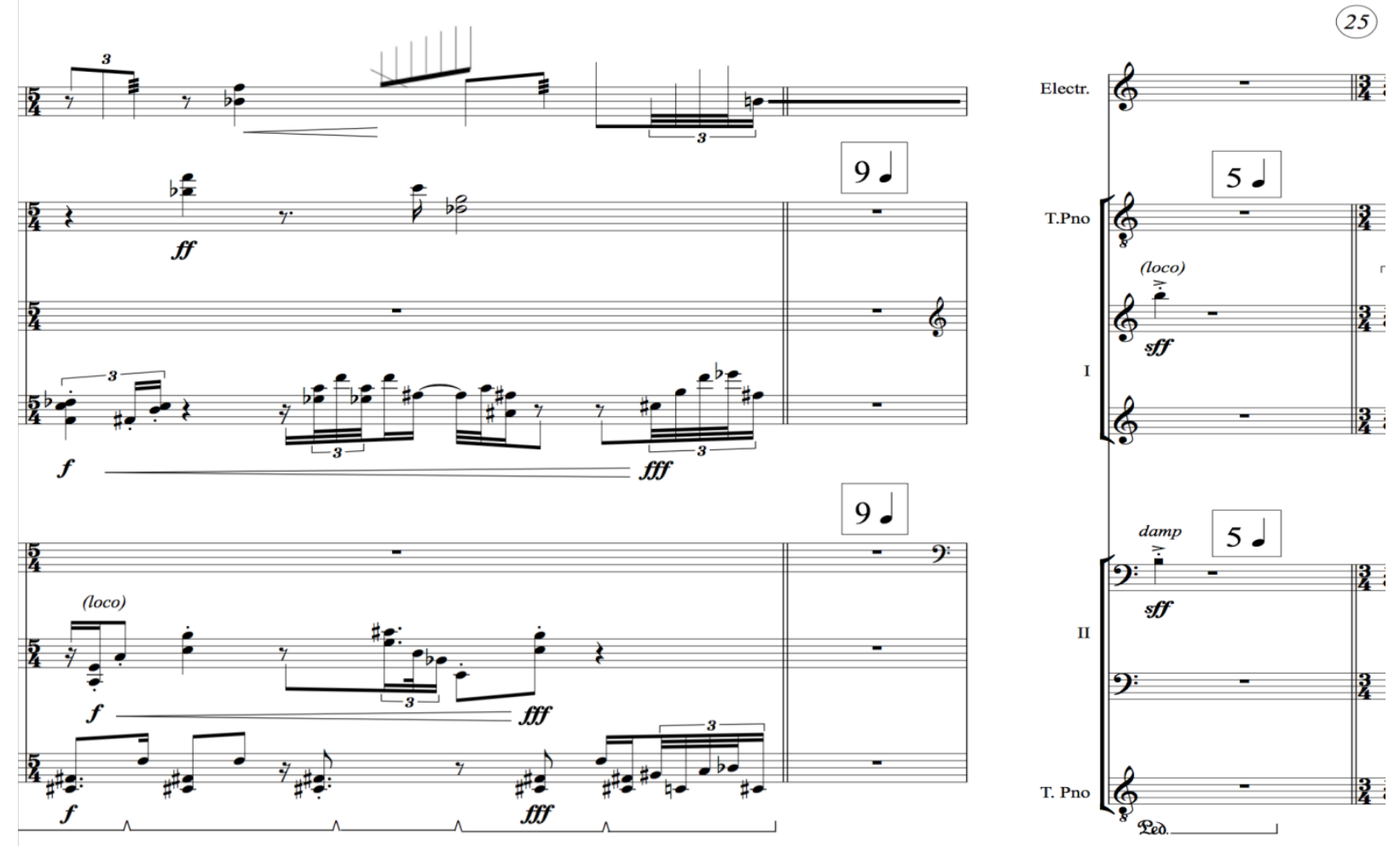

Figura 9 - C. 22-24 de Titanium

Fonte: OLIVEIRA, 2014.

Na direção contrária, o gesto eletrônico em direção ao agudo é recorrente para marcar o início das seções (por isso, será chamado de material inicial - MI). Esse material é um dos principais articuladores nesta peça, realizando a função de abrir todas as grandes seções e, ainda, a segunda seção de $A$ (Figura 6).

A forma como o compositor cria articulações formais em sua obra comprova a eficácia das postulações de McAdams e Saariaho (1985). Ainda mais, vão ao encontro do pensamento musical de Pierre Boulez que, ao analisar sua peça Sur Incises, no documentário A lesson by Pierre Boulez de 1999, discorre sobre esse mesmo efeito, chamando-o de Reflexo de Pavlov. De acordo com Boulez, as atribuições de funções específicas a determinadas características musicais levam o ouvinte a entender aquele sinal como portador de um significado. Este procedimento tem uma semelhança próxima com a linguagem e a criação de 
um idioma. Podemos então inferir que os pontos articulatórios de Titanium são impregnados de diversas codificações construídas de forma a otimizar a transmissão de mensagens criadas pelo compositor e destinadas aos ouvintes: transições, continuidades, quebras, inícios, conclusões, e outras.

\section{0 timbre em Titanium}

Segundo McAdams e Saariaho (1985, p. 368), o timbre pode receber duas funções distintas em uma música. Essas funções podem ser estruturais ou ornamentais. Em Titanium, o timbre possui, com frequência, uma importância estrutural. Neste capítulo, serão analisados os procedimentos aplicados para alcançar tal resultado.

De acordo com Lerdahl (1987, p. 137), a criação de hierarquias é de grande importância para o desenvolvimento de estruturas musicais ricas. Para isso, Lerdahl (citado por McAdams e Saariaho, 1985, p. 372) sugere a criação de famílias de sons. Ou seja, sons que, apesar de diferentes, ainda compartilham entre si certas semelhanças espectromorfológicas. A partir desse tratamento, torna-se possível criar um desenvolvimento musical coerente fundamentado essencialmente nas variações tímbricas. Para McAdams e Saariaho (1985):

[A criação de famílias de sons] permite a expressão de variação de graus de contrastes, distância cognitiva, restrições nos caminhos aceitáveis de uma família à outra, e, também, relações que lembram a função de dissonância e domínio que pode ser encontrada na música tonal que são especialmente ricas em suas habilidades para criar formas intricadas desta natureza. (p. 372)

Saariaho (1987, p. 94) faz um paralelo dessa visão à ideia da harmonia. Para a autora, "Quando o timbre é utilizado para criar forma musical é, precisamente, o timbre que toma o espaço da harmonia como elemento de progressão em música”.

Eu fiquei profundamente interessada no fenômeno de transição e sua realização através de diferentes parâmetros. Um sistema de modulação na música tonal pode ser o exemplo de uma transição musical dinâmica que cria senso de movimento. A música é então caracterizada por um poderoso senso de movimento que pode ser reforçado ainda mais pelo uso de outros parâmetros. (SAARIAHO, 1987, p. 104)

Em Titanium, o timbre é um aspecto importante para a criação de movimento, auxiliando a criar transições, bem como o desenvolvimento do discurso musical. A manipulação tímbrica nesta obra vai ao encontro do pensamento de Lerdahl (1987) e Saariaho (1987). João Pedro Oliveira utiliza tanto a ideia de família de sons como também o timbre para criar senso de movimento e progressões musicais.

Nos primeiros compassos da peça (Figura 1) já se tem um claro exemplo da utilização das famílias de sons. O pianista I começa realizando um glissando ${ }^{10}$ pelas teclas brancas do piano utilizando uma palheta dura (imitando o som de um reco-reco), no segundo compasso, o mesmo pianista I realiza um glissando em diversas cordas do instrumento. Por sua vez, o pianista II realiza, no primeiro compasso, um glissando em uma corda só. Esses três sons, apesar de distintos, compartilham uma importante característica espectromorfológica: um caráter rugoso, estriado, que se entende no tempo. Entretanto, cada um também possui características próprias: o glissando utilizando a palheta nas teclas não possui altura definida. Já o glissando em uma única corda possui uma altura definida fixa (a sua variação espectral no decorrer do tempo é pequena), e o glissando normal cruzando diversas cordas 
possui uma altura que varia no tempo.

Tais características são melhores compreendidas ao se analisar os espectrogramas ${ }^{11}$ desses três glissandi (Figura 10, 11 e 12 - excerto áudio 7). O primeiro espectrograma apresenta a análise do glissando imitando o som do reco-reco, deixando clara a forte característica rugosa do som, visível através das faixas verticais distintamente separadas, enfatizando também a falta de ressonância deste tipo de som - um timbre seco, com transitórios bem evidenciados.

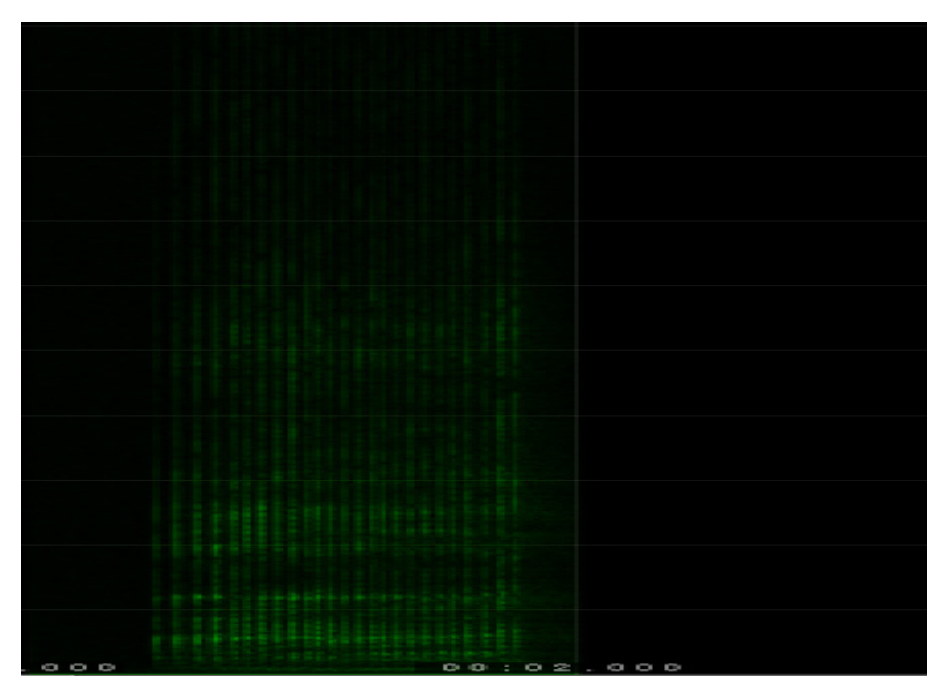

Figura 10 - Espectrograma do glissando feito com paleta sobre as teclas Fonte: OLIVEIRA, 2017.

No segundo espectrograma, encontra-se a análise do glissando feito em uma corda só. Este glissando é feito numa corda grave do piano, aproveitando as saliências dos bordões (Figura 11). Neste caso, pode-se observar a mesma rugosidade sonora (representada igualmente pelas faixas verticais separadas), mas agora ligada a uma forte ressonância, apresentando ainda uma linha branca mais forte na região grave, deixando clara a manutenção de uma altura fixa.
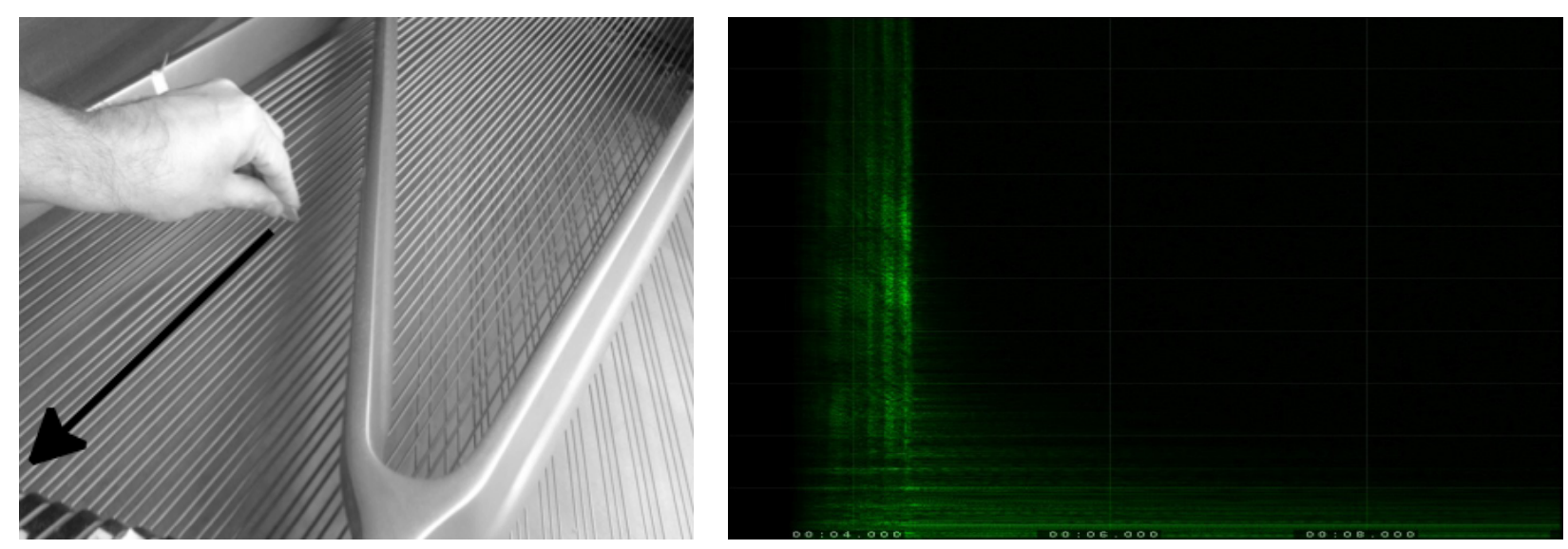

Figura 11 - Forma de execução e espectrograma do glissando sobre uma corda só

Fonte: OLIVEIRA, 2014; 2017. 
O último espectrograma, referente ao glissando em várias cordas, apresenta a mesma rugosidade, sendo agora perceptível a alteração das alturas.

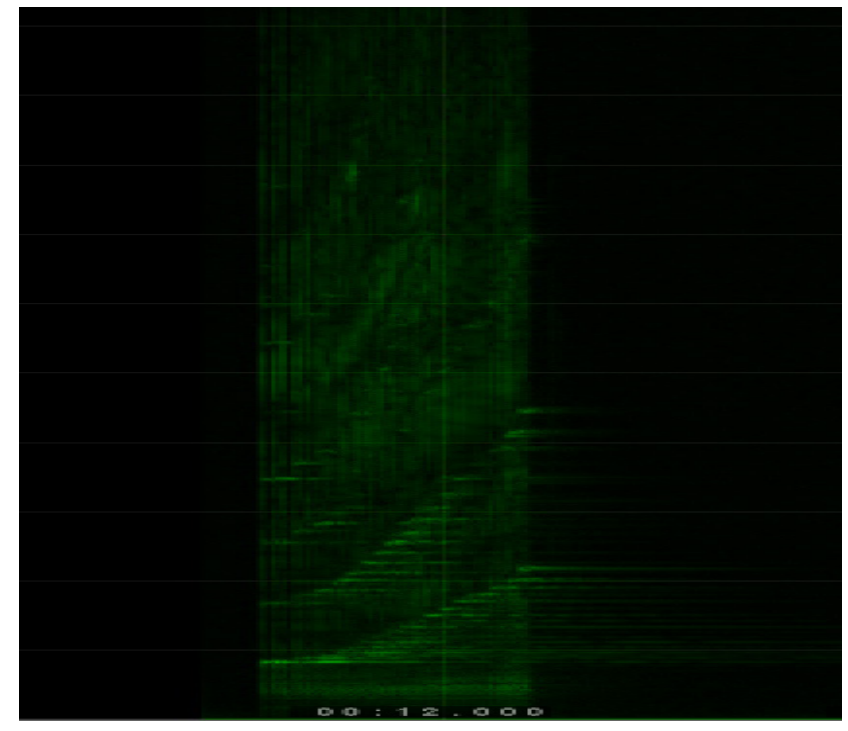

Figura 12 - Espectrograma do glissando através de várias cordas

Fonte: OLIVEIRA, 2017.

O entendimento destas características permite ao compositor uma utilização desses elementos de forma que, quando o ouvinte os ouça, consiga reconhecê-los como sendo relacionados e estruturalmente importantes, mas sempre contendo algum elemento de surpresa, derivado das várias manipulações possíveis (justaposições, sobreposições, contrastes).

A preocupação do compositor com tal processo ${ }^{12}$ possui um grande refinamento e é conduzida minuciosamente no decorrer da música. Utilizando como referência o exemplo anterior, pode-se observar, em menor escala, que o mesmo procedimento também é realizado usando apenas o "som de reco-reco". João Pedro Oliveira faz uso de três sons de reco-reco que possuem diferentes contornos performáticos. O primeiro é realizado passando uma paleta apenas nas teclas pretas do piano, o segundo apenas nas teclas brancas. $\mathrm{O}$ terceiro também utiliza apenas as teclas brancas, entretanto, desta vez, na parte frontal (Figura 13).

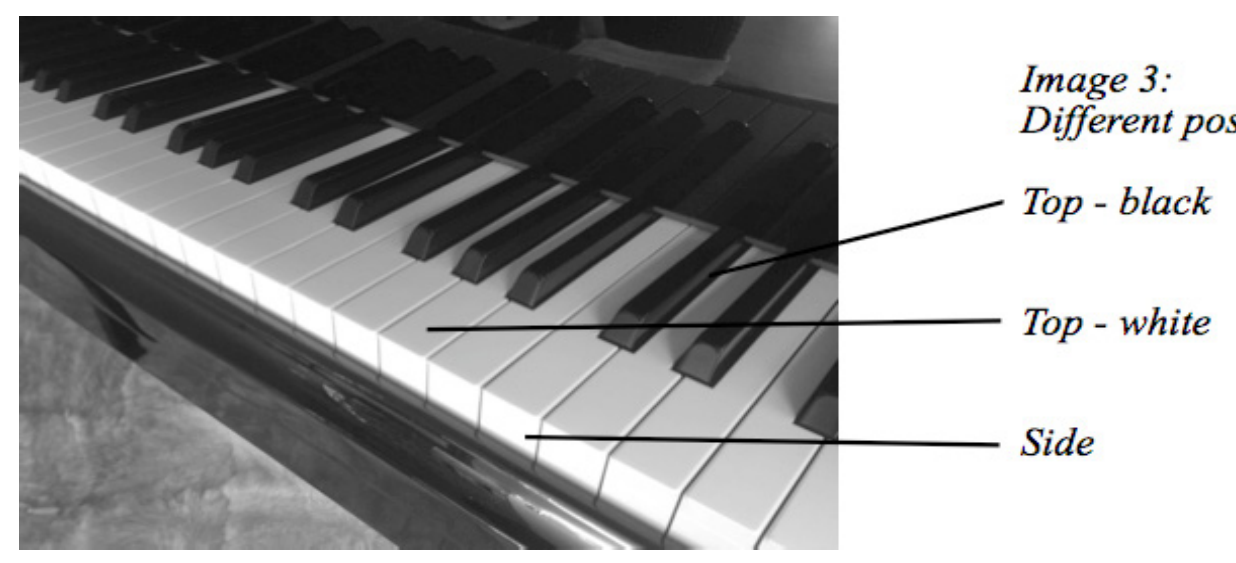

Figura 13 - Excerto da bula de instruções de Titanium

Fonte: OLIVEIRA, 2014. 
Através do espectrograma desses três sons (Figura 14 - excerto áudio 8), a pequena diferença tímbrica pode ser claramente identificada. Tal processo se assemelha à condução de motivos musicais na música acusmática, onde o mesmo som pode passar por processos de filtragem, equalização, entre outros, que mantém as características principais dos sons, no entanto, adicionando/retirando harmônicos de diferentes regióes do espectro, gerando novidades tímbricas.

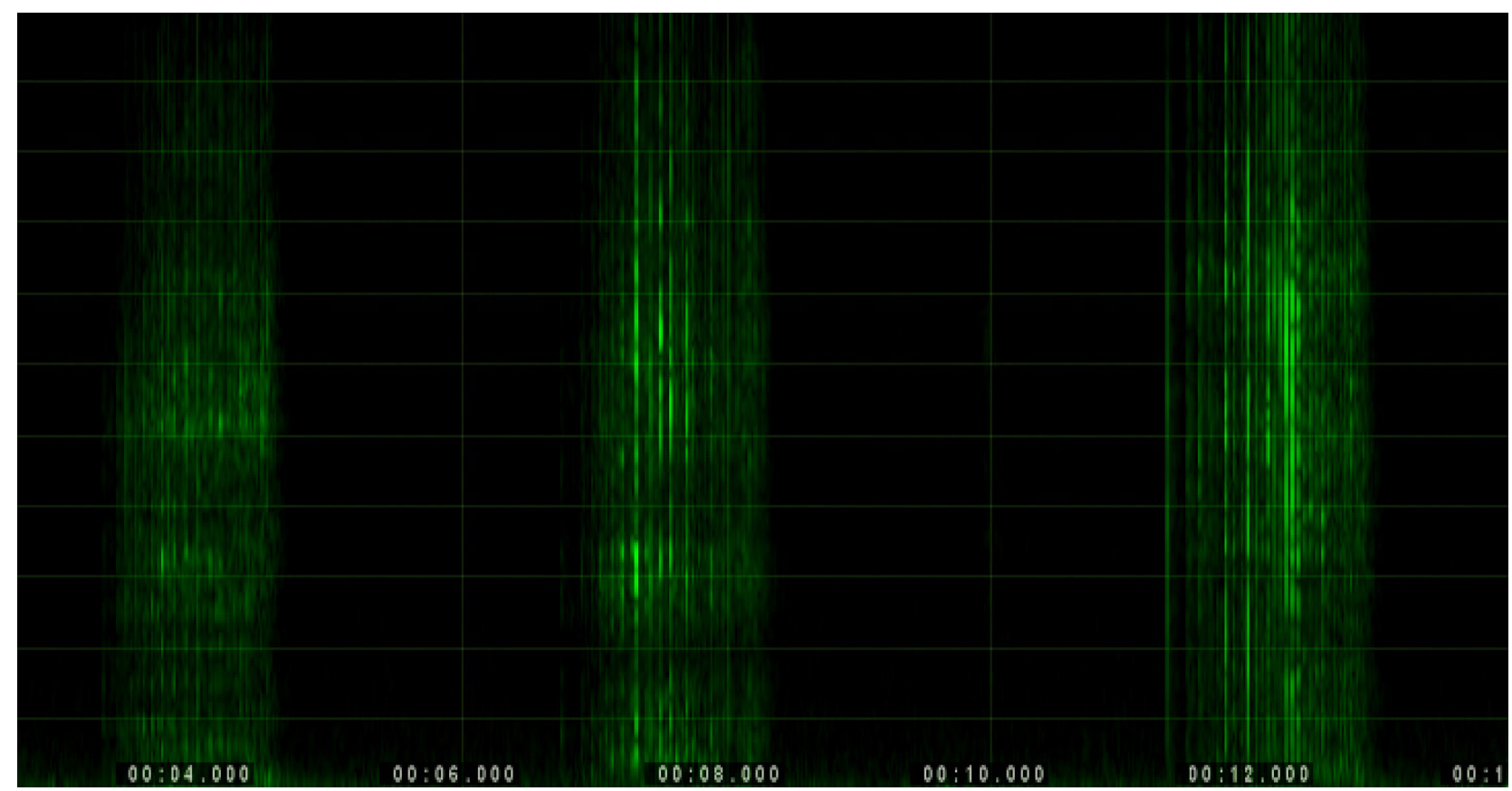

Figura 14 - Espectrograma dos três tipos de "som de reco-reco"

Fonte: OLIVEIRA, 2017

Outra característica tímbrica importante que gera senso de movimento em Titanium é a manutenção de alturas definidas em certas frases musicais, variando apenas o timbre através do uso de técnicas estendidas. Para exemplificar tal procedimento, serão utilizados os três primeiros compassos da última seção da peça (compassos 117 a 120 - Figura 15 - excerto áudio 9). A eletrônica retoma o material utilizado nos três compassos que iniciam a peça (Figura 1), mas neste excerto a escrita para o piano está mais rarefeita e utiliza diversas técnicas estendidas - damp em algumas notas e uma utilização mais enfática dos glissandi nas teclas brancas.

Como se pode ver na Figura 15, o motivo inicial da obra em Dó, Sol, Fá\# do piano de brinquedo (Figura 1 - compasso 1) reaparece no grave do piano, agora abafado e em ritardando. A segunda aparição desse motivo acontece no piano de brinquedo I (compasso 118), mais curta que seu correspondente no compasso 2 e, por ser tocada apenas no piano de brinquedo, possui um timbre com menos presença, dando lugar a uma maior valorização dos glissandi. O gesto que finalizava a frase musical no início da música (quarta semínima do compasso 3) nesta seção conduz a um ataque do piano em damp (quinta semínima do compasso 118 e primeira do compasso 119). Essas alterações tímbricas criam uma perspectiva diferenciada em relação ao todo, gerando a impressão que essa volta ao material inicial ocorre como uma ressonância de tudo o que se passou na obra. Assim, apesar das alturas utilizadas serem essencialmente as mesmas, a ideia de progressão musical fica a cargo do timbre, indo de encontro à perspectiva de Saariaho (1987). 


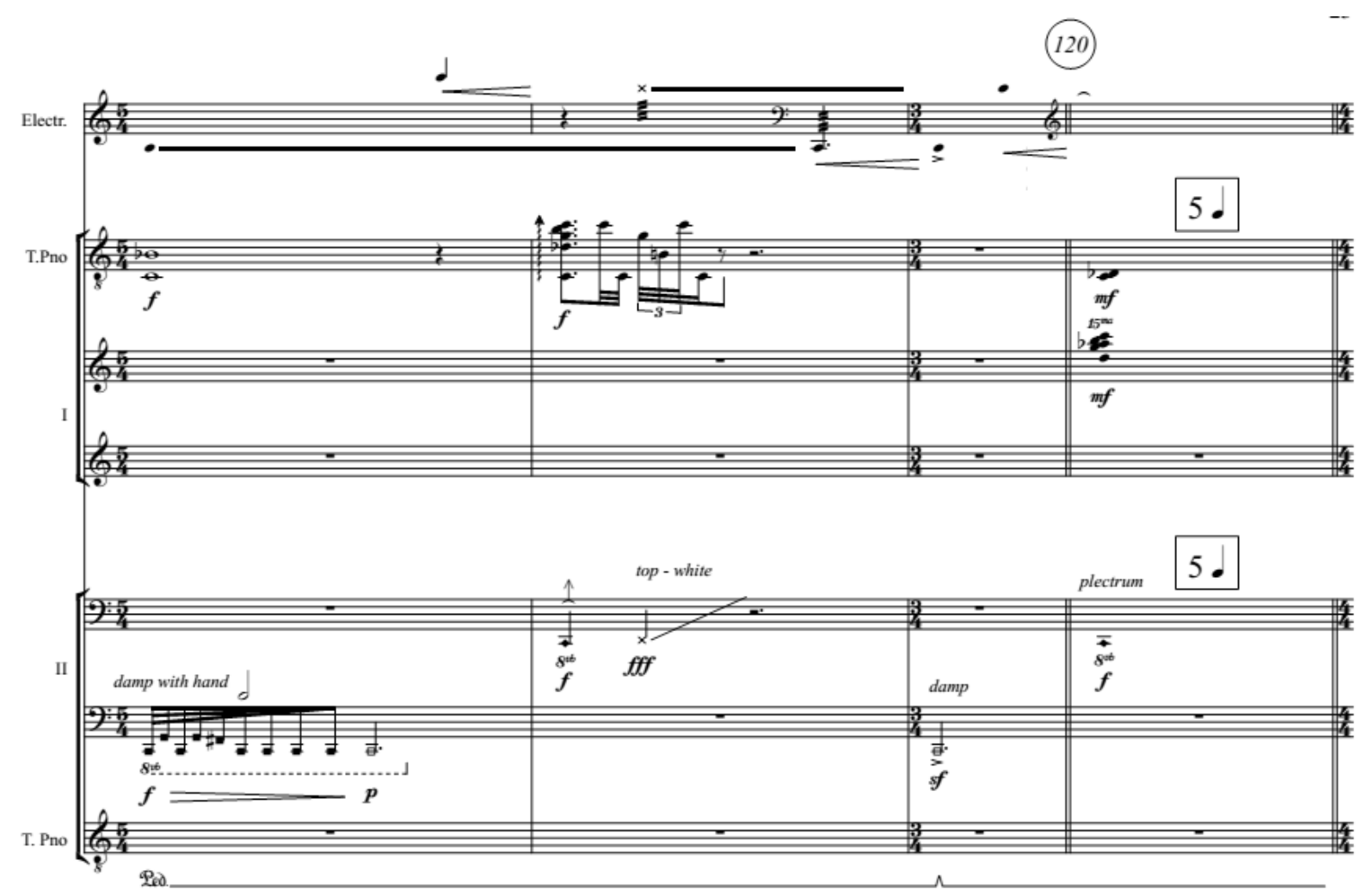

Figura 15 - C. 117-120 de Titanium

Fonte: OLIVEIRA, 2014.

O desvanecimento tímbrico nesse momento da peça tem uma grande relevância formal. O material que anteriormente foi apresentado no começo da peça de forma muito clara, tanto em altura e timbre, reaparecem na coda, com a altura abafada e com uma intensidade moderada por causa dos damps. Este procedimento pretende sugerir que nos aproximamos do final da obra.

Os procedimentos apresentados nos parágrafos anteriores são recorrentes em diversos momentos de Titanium e exemplificam a forma como as relações tímbricas podem aportar riqueza à música. A existência de interação entre os instrumentos acústicos e os meios eletrônicos acresce uma importância especial a este fato.

\section{Interação entre meios acústicos e eletrônicos}

Como recorrente na obra musical deste compositor, a mídia utilizada em Titanium é a eletrônica pré-gravada. Segundo Oliveira (2010):

Sons instrumentais devem soar como sons instrumentais e sons eletrônicos devem manter suas particularidades sonoras. A transformação em tempo real da execução instrumental [...] não representa um caminho interessante [...]. No primeiro caso as razões prendem-se com a unidirecionalidade do percurso interativo, [...] a transformação em tempo real inicia-se sempre no instrumento e projeta-se [...] na eletrônica, porém o percurso contrário não se encontra ainda suficientemente implementado nos atuais sistemas informáticos de transformação em tempo real ${ }^{13}$. (p. 68)

Além disso, a crítica de Boulez referente à incapacidade da eletrônica fixa de criar interações bem-sucedidas é facilmente rejeitada, uma vez que o sucesso da intera- 
ção não irá depender da mídia utilizada, mas sim do trabalho da composição e da organização das relações rítmicas, harmônicas, tímbricas, etc. entre os instrumentos e a parte eletrônica pré-gravada. Quanto mais bem organizada está a estrutura da composição e seus elementos expressivos, mais satisfatório o resultado, sendo esse aspecto vital para que o tempo musical não seja perceptível como rígido.

Além da preferência pela eletrônica fixa, ao ouvir a obra de João Pedro Oliveira, torna-se perceptível a preocupação do compositor com a interação entre os campos "real” e "virtual”, sendo o campo "real” representado pela execução instrumental e o campo "virtual" representado pelos sons eletroacústicos pré-gravados. Nos compassos 33 a 37 (Figura 16 - excerto áudio 10) encontra-se uma amostra desta interação.

Ao se ouvir a passagem, é perceptível a dificuldade em definir auditivamente quando a mudança de campos acontece, ou seja, o momento preciso em que os sons acústicos se transmutam para a eletrônica. O gesto musical começa com notas repetidas no piano de brinquedo I (primeiro compasso - Figura 16) ao qual se junta o piano de brinquedo II (segundo compasso - Figura 16). No meio deste gesto, a eletrônica realiza um som rugoso com as mesmas notas que são realizadas pelos pianos de brinquedo. A eletrônica começa piano e ganha força, recebendo mais protagonismo a partir do terceiro compasso do exemplo, no qual os dois pianistas já não tocam. Esse efeito de fade in - fade out combinado à similaridade dos sons eletrônicos e acústicos (no que diz respeito às alturas e sua espectromorfologia) garantem uma passagem bem-sucedida entre os campos "real" e "virtual".
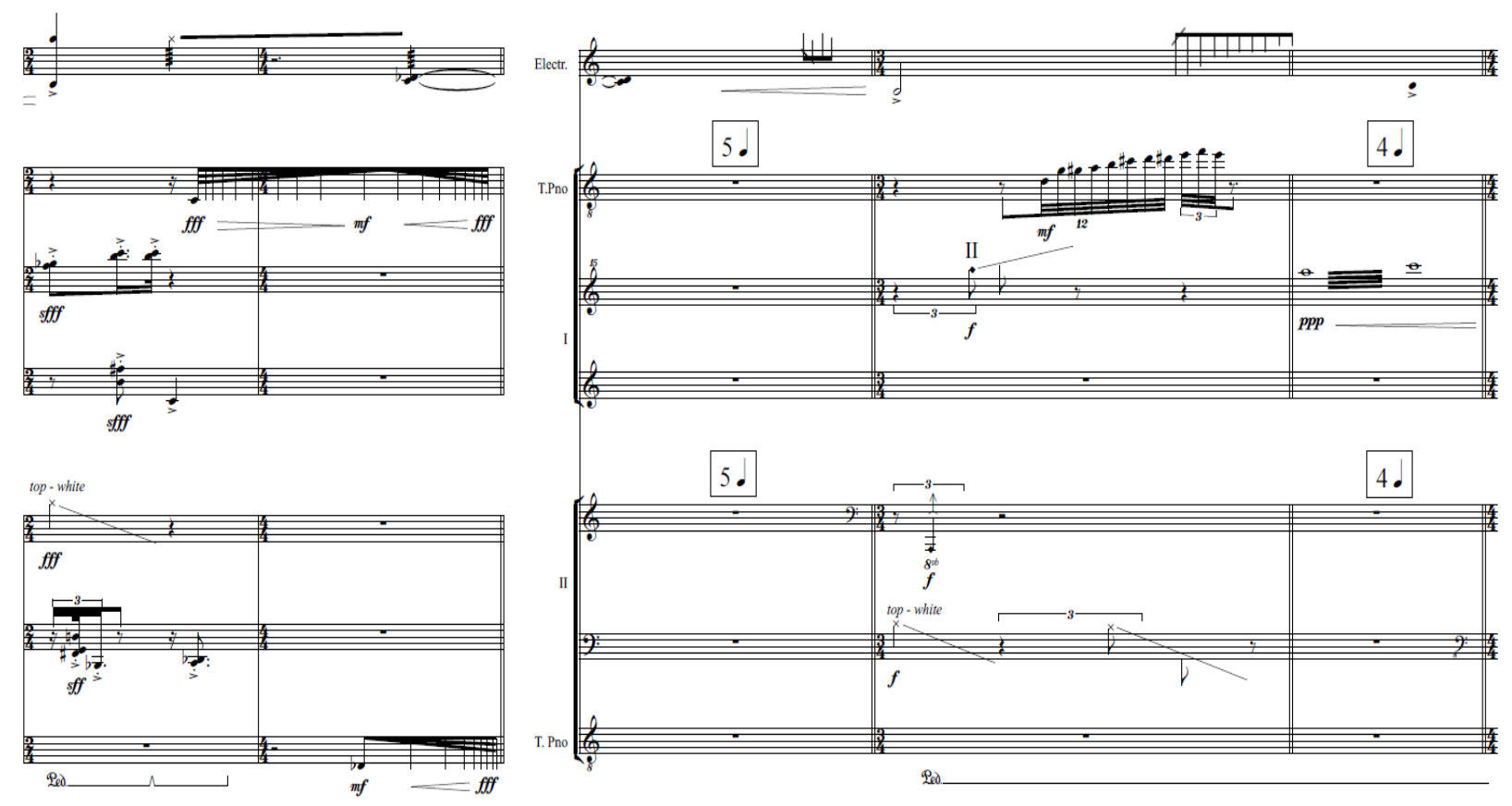

Figura 16 - C. 33-37 de Titanium

Fonte: OLIVEIRA, 2014.

No compasso 36 (quarto compasso - Figura 16), a música volta novamente ao campo do "real". Para isso, as técnicas estendidas são utilizadas como porta de conexão. O primeiro som realizado pelo pianista II é o glissando imitando um reco-reco (quarto compasso - Figura 16). Esse elemento aprimora a interação, pois seu timbre único e surpreendente se afasta de um som tradicional pianístico, gerando dúvida no ouvinte em relação a sua fonte 
sonora, levando-nos, assim, de volta aos sons acústicos que se irá seguir.

As características dos três tipos de glissandi discutidas anteriormente são aqui exploradas: o timbre seco e sem altura do glissando imitando reco-reco, se transforma em um glissando com timbre harmônico que varia suas alturas, ligando assim novamente ao som instrumental com alturas definidas, realizado no piano de brinquedo I. Nesse momento, a eletrônica realiza sons distorcidos deste gesto, conduzindo a um ponto de interação em que eletrônica e instrumento acústico coabitam.

Na análise desse exemplo, torna-se perceptível como os dois mundos distintos propostos pelo compositor se conectam e trabalham em conjunto. A eletroacústica não é uma entidade separada, sem personalidade, ou de mero enchimento, mas torna-se num instrumentista que dialoga ativamente. Ao se escutar, o resultado assemelha-se ao de um ensemble conciso da tradição musical, sendo que é justamente nesta tradição musical que Oliveira buscou recursos para aprimorar seus processos interativos.

Segundo o compositor (OLIVEIRA, 2010, p. 81), uma de suas maiores influências foram as sonatas de violino e piano de Beethoven. A partir da análise dos processos interativos utilizados por Beethoven para relacionar estes dois instrumentos, foi possível estabelecer vários modelos que propõem gerar uma interação satisfatória entre o meio acústico e o eletrônico. Em Titanium destacam-se:

\section{Inicialização e terminação de frases}

A eletrônica inicia o gesto musical a ser concluído pelo instrumentista (ou vice-versa). Este tipo de procedimento é efetivo para criar interações musicais. O controle de relaxamento e tensão das estruturas musicais é fundamental, sendo que a complementariedade entre os dois campos são a chave para o sucesso. Dennis Smalley (1997, p. 113) classifica três arquétipos morfológicos para essa interação: ataque, sem fase de sustentação; ataque-decaimento, no qual o ataque é rápido, entretanto possui tempo de decaimento (arquétipo típico da ressonância); contínuo gradativo, em que o efeito de fade in ou fade out é gradativo. A partir da classificação de Smalley, Bachratá (2010, p.171) gera diferentes modelos interativos entre instrumentos e eletrônica baseados nesse princípio. A eficácia do método comprova-se também ao se considerar a Auditory Scene Analysis, onde Bregman e Woszczyk (2004) discutem como o sistema auditivo realiza o agrupamento de diferentes sons:

Quando a amplitude dos envelopes dos componentes (musicais) não estão sincronizados é uma evidência que esses componentes são partes de sons produzidos por diferentes fontes. Quando os envelopes estão sincronizados, os componentes são tratados como parte de um mesmo som. (p. 38)

A música de João Pedro Oliveira pode ser utilizada para comprovar essas teorias, pois esse procedimento é um dos mais utilizados por ele e está presente em diversas seções de Titanium. Logo nos primeiros compassos (Figura 1 - excerto áudio 1) aparecem dois exemplos. Após o gesto inicial, a eletrônica reverbera sozinha e começa a ganhar força, gerando tensão na estrutura musical. Esse acúmulo de tensão leva a um ataque do piano (compasso 2, piano I). Após o ataque do piano, a eletrônica, que antes ganhava força, começa a se esvair. Junto a isso, o efeito de granulação adicionado na eletrônica acresce à ideia de que a tensão acumulada foi destruída pela intervenção do pianista. Ao fim do mesmo exemplo, é perceptível como a eletrônica cria de novo a tensão que é dissipada pelo ataque no grave do piano (compasso 3, piano II), terminando a ideia musical. 


\section{Imitação}

Imitação é uma das soluções mais antigas encontrada por compositores para conectar ideias musicais advindas de diferentes fontes e, por isso, se tornou um procedimento importante em todos os períodos históricos da música europeia. Portanto, como se pode esperar, também é um importante recurso de interação na música mista.

Petra Bachratá (2010) também destaca a efetividade da interação através de imitação na música acusmática, nomeando-a interação via gestos contrapontísticos. Os princípios anunciados pela autora também podem ser aplicados na criação de música mista. Segundo Bachratá (2010),

Embora os conceitos de contraponto tenham sido desenvolvidos para a prática composicional convencional, seu potencial de construir relações entre estruturas musicais e eventos na música acusmática já tem sido reconhecida. O estudo e escuta de peças eletrônicas mostram que esses métodos tem sido intuitivamente ou intencionalmente utilizados de forma simples ou complexa em várias composições acusmáticas. (p. 175)

Em Titanium é possível encontrar imitações em diversos momentos. Nos compassos 10 a 12 (Figura 17 - excerto áudio 11), a imitação é utilizada duas vezes. Logo no começo, a melodia com direcionamento à região grave, realizada no piano, é seguida de um gesto similar na eletrônica. E, no final do exemplo, as notas repetidas do piano reaparecem sintetizadas na eletrônica.
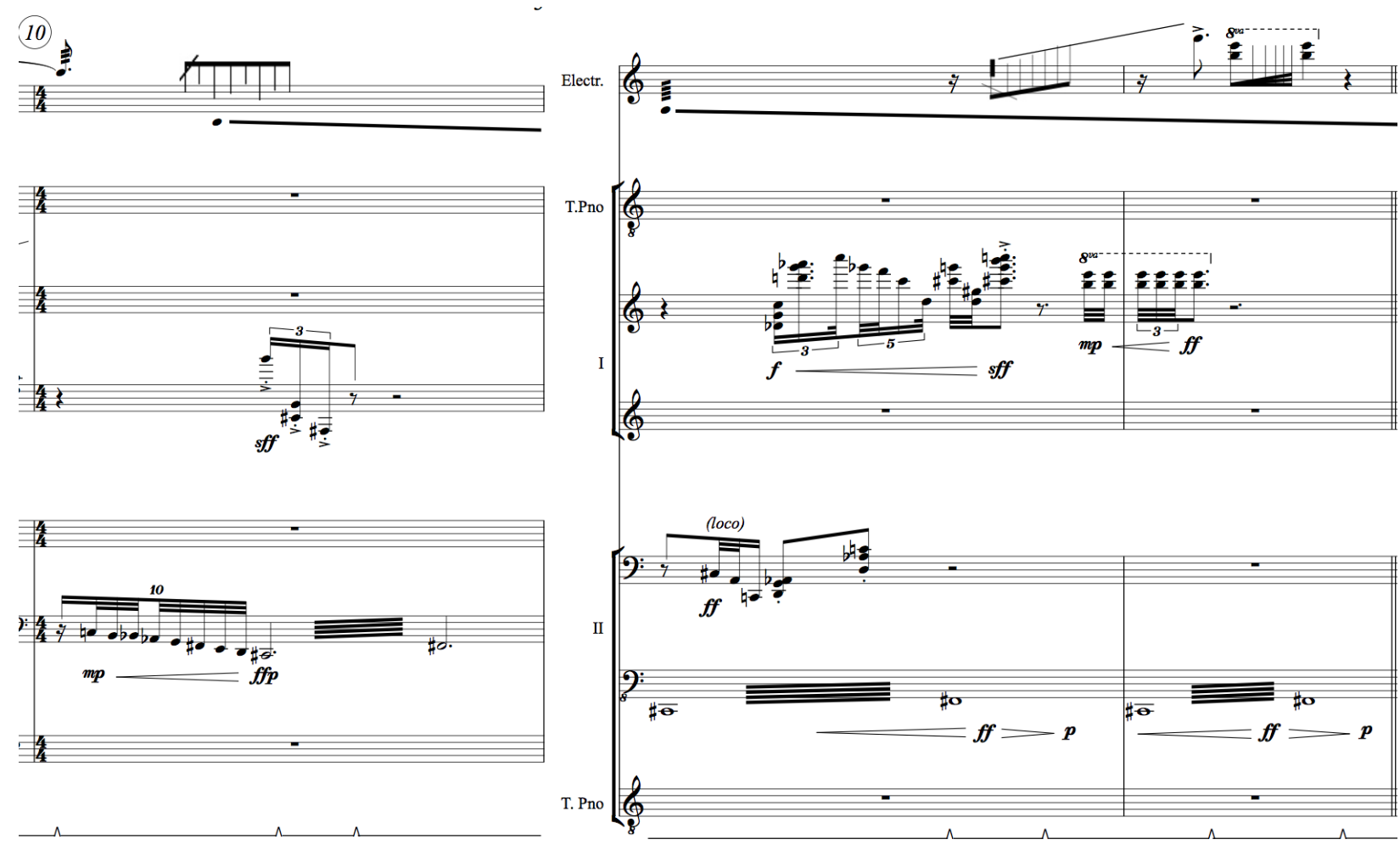

Figura 17 - C. 10-12 de Titanium

Fonte: OLIVEIRA, 2014. 


\section{3) Complementação e sobreposição tímbrica}

Tal modelo interativo ocorre quando diferentes sons são sobrepostos com o objetivo de criar um novo timbre. Oliveira (2010, p. 83) propõe quatro morfologias para esse tipo de interação: Convergente/divergente, expansiva/contrativa, ressonância e repetitiva. Três delas aparecem nos últimos compassos de Titanium (Figura 18 - excerto áudio 12).

O primeiro tipo é a morfologia convergente, em que uma parte realiza o mesmo movimento direcional que a outra parte, em simultaneidade temporal ou rítmica. Isso é o que acontece quando os pianos de brinquedo executam uma melodia para o agudo ao mesmo tempo que a eletrônica. Ao fim da melodia executada nos pianos de brinquedo, o movimento em direção à região aguda continua na eletrônica, representando outro tipo de morfologia, a expansiva, na qual uma parte expande o movimento da outra. Opondo-se à morfologia convergente, temos a divergente, em que os movimentos gestuais têm direções opostas; finalmente, em oposição à morfologia expansiva, temos a morfologia contrativa, que acontece quando uma parte contrai o gesto da outra.

A terceira é a morfologia de ressonância, na qual uma parte cria ressonância para a outra com eventuais transformações. Isso é o que acontece nos acordes acentuados realizados pelo piano ao fim do exemplo musical. Em cada ataque do piano, a eletrônica ressoa de uma forma diferente, adicionando cor e interesse à textura musical.

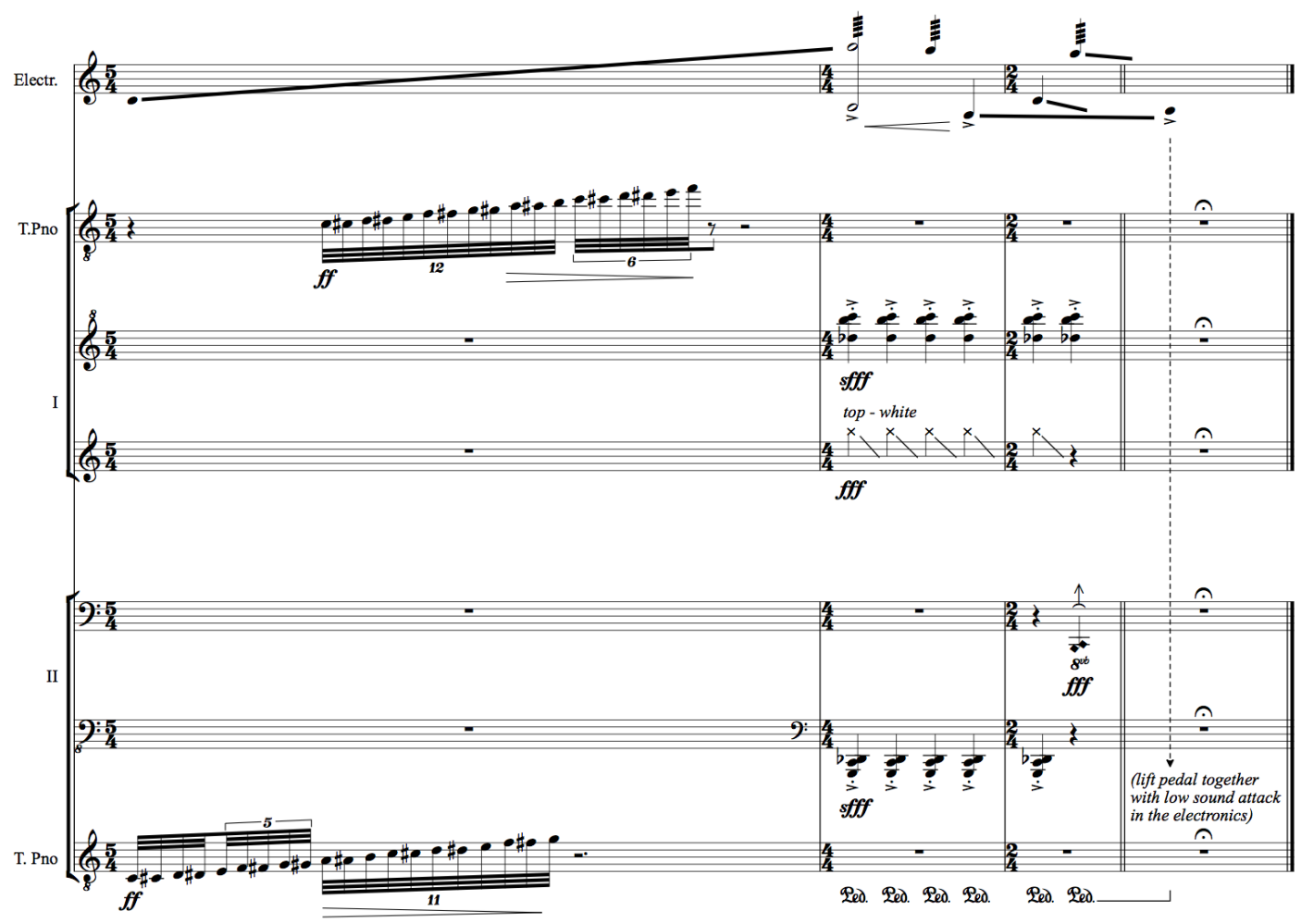

Figura 18 - C. 141-144 de Titanium

Fonte: OLIVEIRA, 2014.

O quarto tipo de morfologia, a morfologia repetitiva, acontece quando "uma célula ou gesto musical, apresentado numa das partes, pode dar origem a vários tipos de interação, por meio da sua repetição ou mera prolongação em loop.” (OLIVEIRA, 2010, p. 83). Em Titanium, esta morfologia está presente no compasso 72 (Figura 19 - excerto áudio 13), em que o glissando é prolongado pela sua repetição na eletrônica. As repetições são filtradas de di- 
ferentes formas, portanto, cada uma apresenta uma peculiaridade sonora única, apesar de ainda soar semelhante às anteriores.

Esse exemplo traz duas considerações importantes. Woszczyk e Bregman (2005, p.16) afirmam que a filtragem aumenta a percepção de distanciamento entre sons, dizendo que um som filtrado com um high-pass ou low-pass (por exemplo) soaria distinto e tenderia a se destacar e não misturar no contexto no qual é apresentado. Não é o que ocorre nesta passagem: os sons filtrados soam como um conjunto e integram-se musicalmente de forma coesa. Em sua colocação, Woszczyk e Bregman (2005) levaram em consideração apenas sons ocorrendo simultaneamente. No entanto, a mesma técnica de filtragem pode ser útil para unir sons em sequência, pois o comportamento espectromorfológico do som continua muito semelhante, apesar do timbre se tornar ligeiramente diferente. Desta forma, neste exemplo, como afirmado por Saariaho (1987, p. 94), "é exatamente o timbre que toma o lugar da harmonia, de ser o elemento progressivo na música."
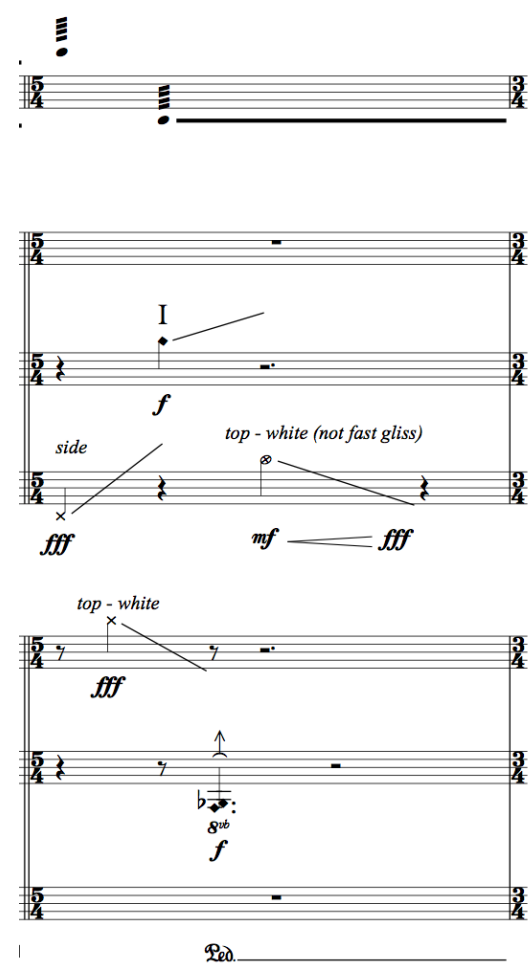

Figura 19 - C. 72 de Titanium

Fonte: OLIVEIRA, 2014.

\subsection{Modelos de Interação}

Além dos recursos advindos da tradição musical, João Pedro Oliveira (2010, p. 69) define cinco modelos genéricos de interação: Independência entre partes, padrão rítmico, ressonâncias, similaridade entre materiais e extensão dos limites do instrumento. Para a análise de Titanium, serão discutidos três desses modelos com mais ênfase, eles são: Padrão rítmico, similaridade entre materiais e extensão dos limites instrumentais.

Do compasso 44 ao 46 (Figura 20 - excerto áudio 14), a primeira grande seção de Titanium está chegando ao fim. Para demarcar o fim da seção, Oliveira utiliza fortes ataques na região grave do piano e a resposta dada a esse gesto pela eletrônica resulta em uma poderosa interação através de padrões rítmicos. Para Bregman e Woszczyk (2004, p. 39), esse ti- 
po de agrupamento seria sequencial, pois ocorre através da junção de duas linhas distintas no decorrer do tempo como se fossem uma só. Em agrupamentos desse tipo, os autores classificam duas características como essenciais: 1) prover padrões que o ouvinte possa seguir no decorrer do tempo; e 2) influenciar o agrupamento automático entre os sons que aparecem em sequência. Nesse exemplo, tais características são encontradas. A alternância entre os ataques da eletrônica e piano geram um padrão que ajuda o ouvinte a conectá-los como oriundos de uma mesma fonte, pois ambos têm um comportamento similar. A utilização das mesmas alturas no instrumento e na eletrônica influencia no agrupamento automático entre os sons de ambas as partes.

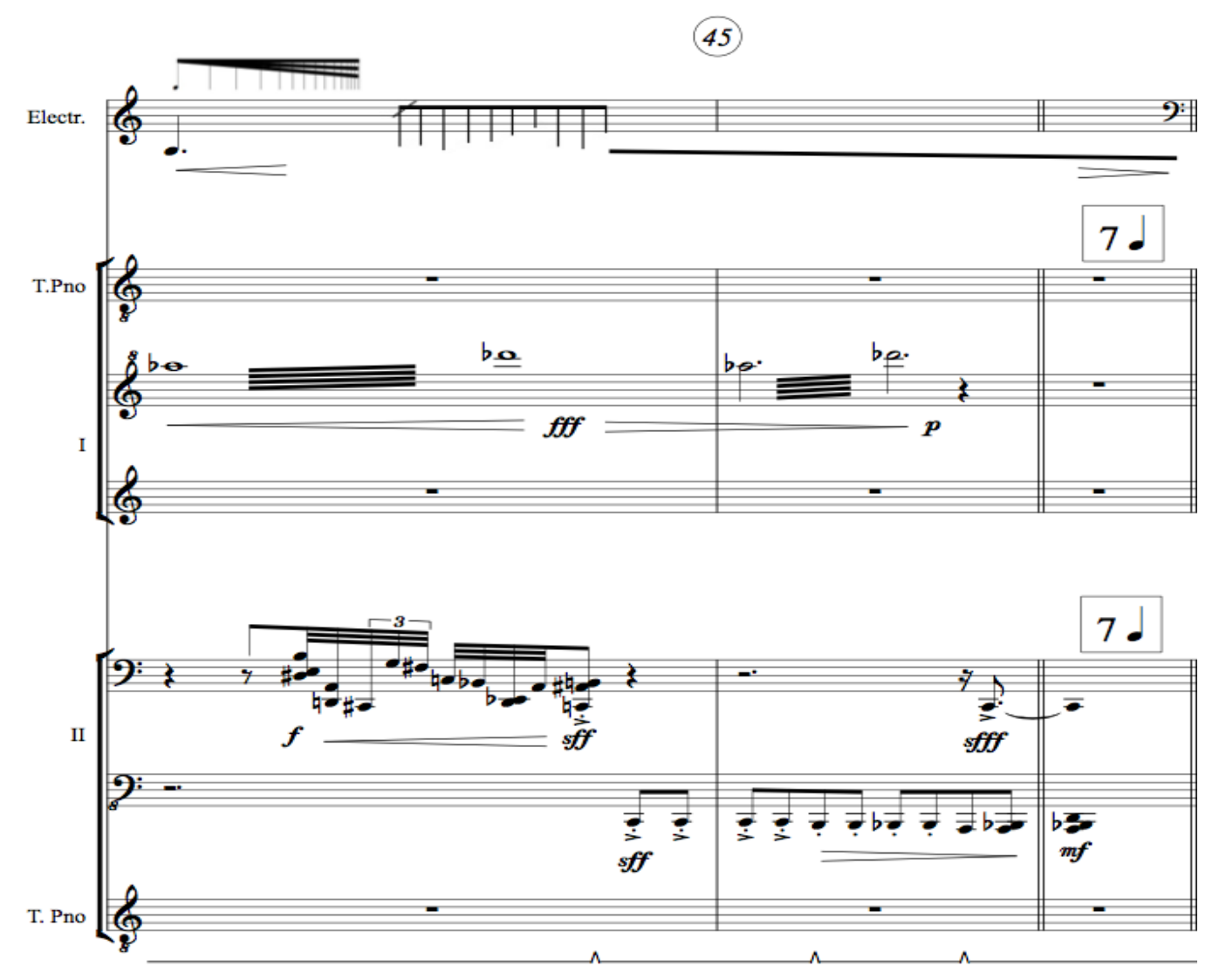

Figura 20 - C. 44-46 de Titanium

Fonte: OLIVEIRA, 2014.

O mesmo efeito pode ser alcançado em contextos mais complexos. Entre os compassos 20 e 23 (Figura 21 - excerto áudio 15), a música se encontra em um ponto mais textual que gestual. Ambos os pianistas tocam acordes com diferentes ritmos, criando uma estrutura polirrítmica. Nessa estrutura, algumas notas começam a ganhar mais importância, entre elas, a nota Dó aparece diversas vezes e em diferentes registros. Para criar a interação na passagem, Oliveira utiliza essas notas mais importantes para criar melodias na eletrônica. Essa forma de interação deixa a ideia musical realizada pelos instrumentistas mais complexa e intensifica o contraponto rítmico e melódico. O uso das mesmas alturas é de grande relevância para o processo de interação, no entanto, outra característica também tem importância: Oliveira usa sons de piano sintetizados para compor a eletrônica. Portanto, o timbre também ajuda a conectar campo "real” e "virtual". Sendo assim, da mesma forma que no exemplo anterior, alguns padrões são mantidos para que o ouvido possa conectar e relacionar os materiais musicais como se fossem provenientes de uma única fonte. 

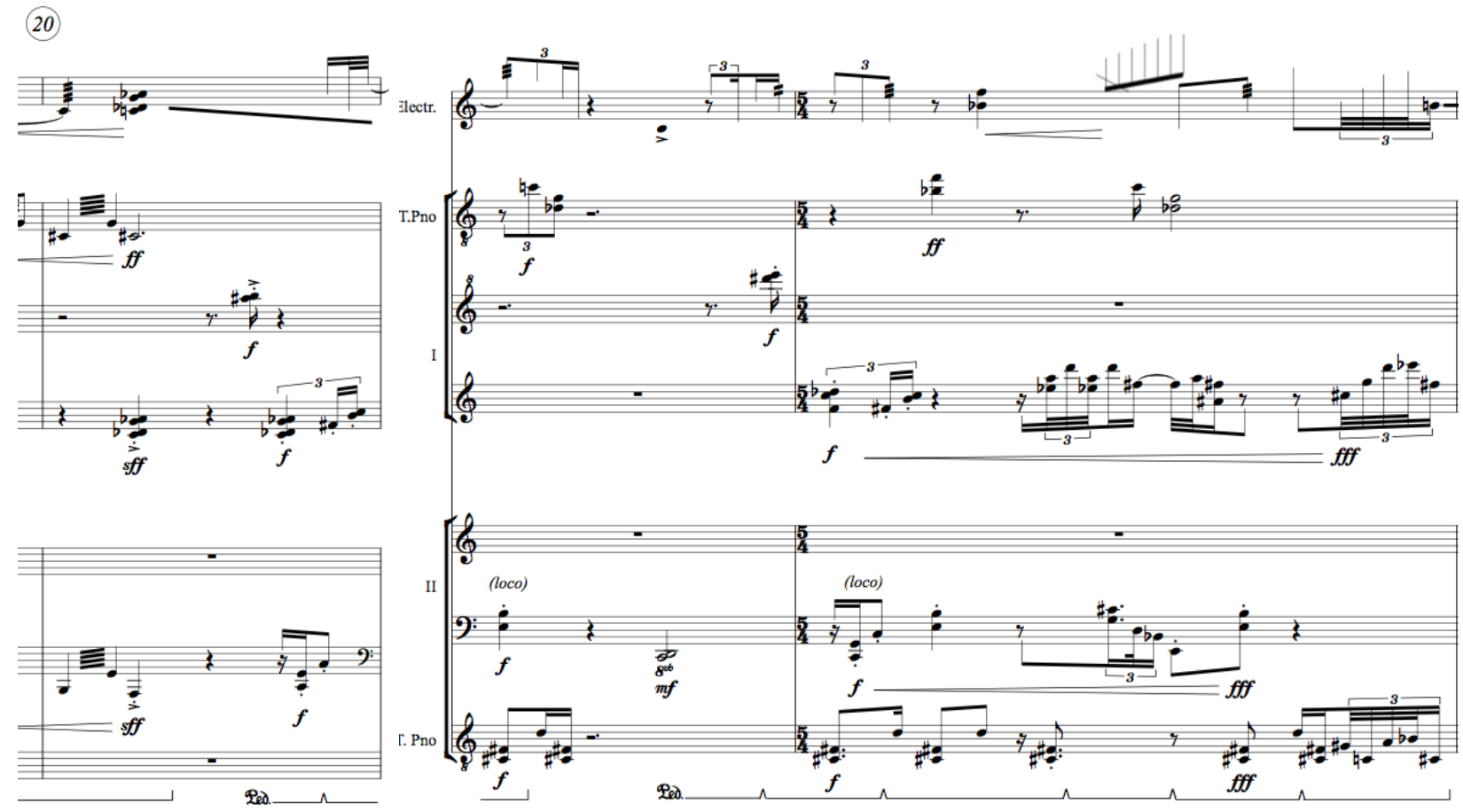

Figura 21 - C. 20-22 de Titanium

Fonte: OLIVEIRA, 2014.

O último aspecto a ser discutido será a extensão de limites instrumentais. Tal aspecto também tem um papel de protagonismo na música de João Pedro Oliveira. De acordo com o compositor (2010),

Os sons electrónicos podem também assumir o papel de prolongamento virtual dos sons instrumentais que, pela sua natureza, estão sujeitos aos limites que a forma, estrutura e características físicas do instrumento lhe impõem (não é possível fazer um piano tocar glissandi como um violino, nem um violino atacar uma nota de forma percussiva como o piano) [...]. Este tipo de interação tem múltiplos aspectos que podem ser considerados: limites da intensidade ao qual o instrumento está confinado, limites impostos pela estrutura física do instrumento, limites impostos pela dificuldade de execução e limites tímbricos. (p. 73)

Segundo Smalley (1997, p. 107), a espectromorfologia é uma teoria analítica desenvolvida para ajudar os compositores a entenderem os processos que estão envolvidos na música eletrônica. O objetivo desta teoria é descrever a experiência auditiva do ouvinte. Entretanto, também pode ser muito útil para a composição de música eletrônica. Segundo Smalley (1997):

Embora a espectromorfologia não seja uma teoria composicional, ela pode influenciar em métodos composicionais a partir do momento que o compositor se torna consciente dos conceitos e palavras que a diagnosticam e a descrevem, desta forma, o pensamento composicional pode ser influenciado, como o meu, certamente foi. (p. 107)

Nessa teoria, duas características do som são tomadas como principais: o espectro sonoro e como ele se desenvolve no tempo. Consciente dessas características, o compositor pode buscar formas de utilizá-las na realização de interações entre os meios acústicos e eletrônicos. Entre os vários termos propostos por Smalley, source bonding (SMALLEY, 1997, p. 110) é muito útil para a análise de Titanium, pois refere-se a materiais musicais que aparen- 
temente compartilham a mesma origem ou possuem comportamentos semelhantes. Smalley (1997) explica esse termo da seguinte maneira:

Existe uma diferença sútil em níveis de identificação entre uma afirmação que diz, 'isso são pedras caindo', uma segunda que diz, 'isso soa como se pedras estivessem caindo' e uma terceira que diz, 'Isso soa como se tivesse o comportamento sonoro de pedras caindo'. Todas as três afirmações são conexões extrínsecas, mas em estágios que aumentam a incerteza e o distanciamento da realidade. (p. 110)

Esse pensamento pode ser levado para a música mista. O compositor pode pensar nessas características ao fazer a parte eletrônica, sendo um ótimo recurso para ligar sons eletrônicos e acústicos, pois o instrumento acústico seria o correspondente ao primeiro nível de identificação ("isso são pedras caindo") e o meio eletrônico ficaria responsável pela implementação dos outros dois níveis ("Isso soa como se pedras estivessem caindo" e "Isso soa como se tivesse o comportamento de pedras caindo") ${ }^{14}$. Desta forma, apesar das diferentes fontes sonoras (instrumento e caixas de som), os sons utilizados na composição ainda compartilham características comuns.

Em Titanium, um exemplo desse pensamento pode ser encontrado já em seus primeiros compassos (Figura 1 - excerto áudio 1), nos quais o som de reco-reco é estendido. Logo após a realização do glissando, a eletrônica o prolonga. A partir do instante em que o som foi transferido para a eletrônica, o compositor se encontra diante de infinitas possibilidades de alterar como o som soa e se comporta. É possível variar tamanho, registro, velocidade, entre outros. Espacialização também é uma ferramenta preciosa nesse caso, pois adiciona um movimento ao som que seria impossível de ser feito no meio acústico. $\mathrm{O}$ compositor faz exatamente isso, pois quando o som de reco-reco se inicia na eletrônica, ele começa um movimento circular entre as caixas de som (Figura 22). Desta forma, a eletrônica amplia o nível de identificação da parte instrumental, pois, apesar do timbre ainda ser parecido, agora ele se comporta de uma forma que seria impossível de ser realizada no piano.

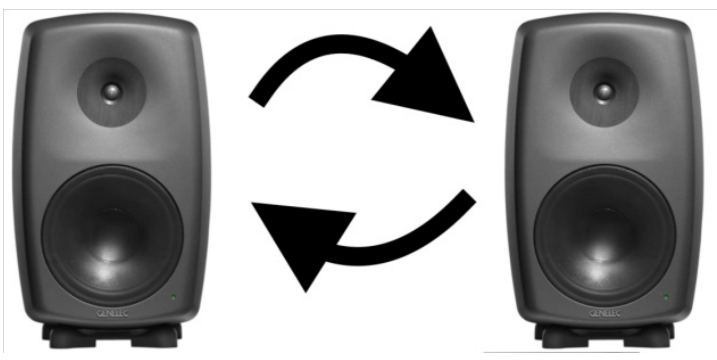

Figura 22 - Esquema de espacialização do som de "reco-reco"

Fonte: OLIVEIRA, 2017

Do compasso 70 ao 72 (Figura 8 - excerto áudio 5), existe um tratamento ainda mais complexo do mesmo material. Como a seção está baseada apenas em técnicas estendidas, torna-se mais fácil distinguir como os sons acústicos estão interagindo e sendo estendidos pela eletrônica. Neste exemplo, a eletrônica é responsável pelo início do gesto musical.

A busca pela extensão dos limites do instrumento também ajuda a explicar a escolha de algumas fontes sonoras escolhidas para a eletrônica. A parte eletrônica de Titanium possui materiais sonoros advindos da gravação de gestos musicais realizados pelos instrumentos acústicos, nomeadamente o som da palheta nas teclas (simulando reco-reco), ou o glissando numa mesma corda. Alguns destes sons foram trabalhados e transformados no computador e são utilizados simultaneamente ou em contraponto com sua realização no 
meio acústico. A própria contraposição destes sons, confrontando os sons naturais da execução instrumental, e os sons alterados ou distorcidos e eventualmente mais complexos presentes na eletrônica, servem precisamente para alargar as possibilidades tímbricas do gesto musical, seguindo os mesmos critérios que foram apresentados atrás, relativos às mutações e transformações presentes nos motivos instrumentais.

\section{Conclusões}

Devido à complexidade e duração de Titanium, torna-se impossível cobrir todos os seus pontos de interesse em um só artigo. Consequentemente, através desse estudo, buscou-se ressaltar apenas algumas características principais na construção estrutural desta obra de João Pedro Oliveira, que poderão servir de base para futuros trabalhos analíticos mais aprofundados.

Ao relacionar os métodos de desenvolvimento motívico, articulações formais, timbre como aspecto estruturante e a interação de meios acústicos-eletrônicos encontrados em Titanium com a bibliografia de referência utilizada, torna-se claro como o trabalho de nenhum compositor é uma ilha. Os dialogismos são constantes e as preocupações estéticas de uma época sempre caminham em conjunto. De acordo com Oliveira (2010):

Na questão de identidade, a nossa busca será nos pequenos pormenores que podem criar um estilo próprio, inconfundível, mas não auto-plagiado, que tenha significado em comparação com a música que fez no passado e atualmente se faz. Daí o retomar de soluções já experimentadas por outros e que foram suficientemente abertas para permitir diversas interpretações no decorrer da história. Não se pretende imitar, mas sim encontrar ou descobrir modelos e usá-los em proveito de um pensamento atual e único. (p. 133)

A partir da análise realizada, almeja-se alcançar uma maior compreensão da linguagem musical deste compositor, bem como a sua integração e contextualização no momento atual do desenvolvimento da Composição como forma de Arte. A árdua tarefa do compositor dos nossos dias, de se manter atualizado e consciente do trabalho e ideias dos seus contemporâneos, tem como objetivo principal o desenvolvimento de uma linguagem pessoal, em que a relação com o passado e o presente se integram como forma de conhecimento, visando assim a continuação do desenvolvimento da linguagem musical.

\section{Notas}

1 Este trabalho foi realizado com o apoio da CAPES, no âmbito do programa de pós-graduação da UFMG, na linha de pesquisa em Processos Analíticos e Criativos, sob a orientação do professor João Pedro Oliveira. O artigo está inserido no projeto "Construção de Interfaces para Espacialização Sonora 3D e sua Aplicação na Composição", financiado pelo CNPq - Processo: 446978/2014-0.

2 Desde sua estreia, Titanium já foi tocada pelo Brasil e no mundo em diversos festivais. Atualmente, recebeu o primeiro prêmio no renomado Destellos Competition 2016, organizado pela Fundação Destellos (Buenos Aires/ Argentina).

3 Ciclo de obras para instrumento solo compostas em 1986 e 1987. Integrais I para violino; Integrais II para clarinete; Integrais III para trompa; Integrais IV para saxofone.

4 Os exemplos musicais estão disponíveis em: <https://soundcloud.com/procedimentosestruturaisnaobratitanium $>$.

5 Outros elementos musicais - como ritmo, textura, dinâmica etc. - também colaboram para a criação deste acúmulo de tensão.

${ }^{6}$ João Pedro Oliveira (2010, p. 59) exemplifica essa ideia a partir das definições de quente, morno e frio. Neste caso, se tem uma referência de como é a temperatura no ambiente (ou objeto), entretanto, não se sabe exatamente qual é a temperatura em graus celsius. 
7 Os seis critérios são: 1) Elementos estruturantes são perceptivelmente diferenciados em categorias com similaridades. 2). As categorias são organizadas de forma que criem funções entre elas. 3). As relações funcionais possuem diferentes forças e tipos, permitindo criação e relaxamento de tensão. 4) Atenção tem que ser dada às qualidades de cada categoria (uma nota pode ser apenas uma nota, um intervalo ou um acorde). 5). As categorias, relações funcionais e organização das mesmas devem estar dentro dos limites biológicos de apreensão humana. 6) Relações entre as categorias tem que manter um certo grau de invariância dentro de várias formas de variação.

8 Nesses momentos, o intervalo de oitava tem um papel de destaque. Tal utilização simplifica a harmonia, amplifica o timbre e ressalta, ainda mais, a importância desse motivo na articulação da peça.

9 Neste compasso João Pedro Oliveira utiliza um som eletrônico espectromorfologicamente semelhante a um som de piano com damp.

${ }^{10}$ Apesar deste gesto não estar associado à passagem por diferentes alturas de frequência, o gesto similar ao de um glissando ainda é reconhecível.

11 Foi utilizado o software SpectraLayers Pro 1.0, desenvolvido pela Magix Software GmbH.

12 O processo, descrito acima, de reconhecimento de características tímbricas no decorrer do tempo vem de uma teoria chamada espectromorfologia (SMALLEY, 1986) e será abordada com maior detalhamento no próximo capítulo, onde será discutida a interação dos instrumentos acústicos com a eletrônica.

${ }^{13}$ Essa defesa à eletrônica fixa também pode ser encontrada nos escritos de Menezes (2002, p. 306). Menezes relata que depois da apresentação de sua peça Parcours de l'Entité, no GRM, em 1997, ele recebeu uma carta de Luciano Berio - que também apresentou uma de suas obras no concerto - perguntando porquê Flô Menezes não fazia um maior uso da eletrônica em tempo real. A resposta para Berio foi a seguinte: "Em geral, eu acredito que as estruturas sonoras da eletrônica em tempo real são muito dependentes das estruturas instrumentais, sendo assim, o contraste entre instrumentos e eletrônica nem sempre são alcançados satisfatoriamente."

14 Um exemplo da utilização de source bonding na criação musical encontra-se na obra Lâminas Líquidas, também de João Pedro Oliveira. Nesta peça, o compositor tenta simular o comportamento da marimba como se ela fosse líquida, ou seja, almeja um som que soa COMO SE a marimba tivesse o comportamento de um instrumento fisicamente instável. A importância desse pensamento também pode ser encontrada nos escritos de Flô Menezes, sendo chamado de spectral tranfers. (MENEZES, 2002, p. 311).

\section{Referências}

BACHRATÁ, Petra. Interação gestual na Música para Instrumentos e Sons Electroacústicos. 2010. 349 f. Tese (Doutorado em Música) - Universidade de Aveiro, Aveiro, 2010.

BREGMAN, Albert; WOSZCZYK, Wieslaw. Controlling the perceptual organization of sound: Guidelines derived from principles of auditory scene analysis. In: GREENEBAUM, Ken; BARZEL, Ronen (Ed.). Audio Anecdotes: Tools, tips and techniques for digital audio. Natick, MA.: A. K. Peters, 2004. p. 13-25. (Volume 1).

GUBERNIKOFF, Carole. Pierre Boulez e a análise musical: Notations. Música em perspectiva, Curitiba, v.1, n. 2, p. 30-39, 2008.

KOBLYAKOV, Lev. Pierre Boulez: A world of harmony. Reino Unido: Routledge, 1993. 244p.

LERDAHL, Fred. Timbral Hierarchies. Contemporary Music Review. Reino Unido: Harwood Academic Publishers GmbH, 1987. p. 135-160. (Volume 2)

MCADAMS, Steven; SAARIAHO, Kaija. Qualities and functions of musical timbre. In: INTERNATIONAL COMPUTER MUSIC CONFERENCE, 9., 1985, Canadá. Anais... Simon Frasier University, ICMC '85 Proceedings, 1985. p. 367-374.

MENEZES, Flô. For a morphology of interaction. Organised Sound, Cambridge, v. 7, n. 3, p. 305311, 2002.

OLIVEIRA, João Pedro. Sistema, Intuição e Tempo: Por uma identidade composicional. Texto não publicado. 2010.

OLIVEIRA, João Pedro. Laminas liquidas [música]. Nova York: Mostly Marimba Production, 2012 . 
OLIVEIRA, João Pedro. Titanium [música]. França: Babel Scores, 2014.

SAARIAHO, Kaija. Timbre and Harmony: Interpolations of timbral structures. Contemporary Music Review. Reino Unido: Harwood Academic Publishers GmbH, v. 2, p. 93133, 1987.

SMALLEY, D. Spectro-morphology and structuring processes. In: EMMERSON, Simon et al. (Ed.) The language of Electroacoustic Music. New York: Harwood Academic publishers, 1986. p. 61-93.

SMALLEY, D. Spectromorphology: explaining sound-shapes. Organised Sound, Cambridge, v. 2, n. 2, p. 107-126, 1997.

SOMMER, Andy. A lesson by Pierre Boulez. [Filme-vídeo]. Direção de Andy Sommer. DVD, 49 min. França: EuroArts, 2000.

WOSZCZYK, Wieslaw; BREGMAN, Albert. Creating mixtures: The application of auditory scene analysis (ASA) to audio recording. In: GREENEBAUM, Ken; BARZEL, Ronen (Ed.). Audio Anecdotes III: Tools, tips and techniques for digital audio. Natick, MA.: A. K. Peters, 2005. v. 3. p. 13-25.

Levy Oliveira (1993) é aluno do curso de mestrado em Processos analíticos e criativos pela UFMG, tendo como orientador o compositor João Pedro Oliveira. Sua música tem sido apresentada pelo mundo em festivais como Monaco Electroacoustique 2015 (Mônaco, Mônaco), International Days of Electronic Music - JIMEC 2015 (Amiens, França), MUSLAB 2015 (Cidade do México, México), Open Circuit 2016 (Liverpool, Inglaterra), Festival Tinta Fresca 2016 (Belo Horizonte, Brasil), Cicle Somelgrup 2016 (Valência, Espanha) e EMUFest 2016 (Roma, Itália). Sua peça Hiperestesia recebeu o primeiro prêmio no Concurso de Composição Eduardo Bértola (Belo Horizonte, Brasil), foi obra selecionada no VIII Destellos Composition Competition (Buenos Aires, Argentina) e finalista ao Open Circuit Composition Prize. Sua peça Reminiscências foi selecionada para a XXII Bienal de Música Brasileira Contemporânea, promovida pela Funarte. Sua peça orquestral Um ato de fé recebeu Menção Honrosa no Festival Tinta Fresca 2016, promovido pela Orquestra Filarmônica de Minas Gerais.

João Pedro Oliveira (1959) estudou órgão, composição e arquitetura em Lisboa. Doutorou-se em Música (Composição) na Universidade de New York, em Stony Brook. As suas obras incluem um réquiem, várias obras orquestrais, três quartetos de cordas, música de câmara, música para instrumento solo, música electroacústica e vídeo experimental. Recebeu mais de 50 prêmios internacionais pelas suas obras, incluindo três prêmios no Concurso de Música Electroacústica de Bourges, bem como o prestigiado Magisterium no mesmo concurso, o Prémio Giga-Hertz, o $1^{\circ}$ Prémio no concurso de música electroacústica Metamorphoses, o $1^{\circ}$ Prémio na Yamaha-Visiones Sonoras Competition, duas vezes o $1^{\circ}$ Prémio na Musica Nova Competition, etc.. É professor titular na Universidade Federal de Minas Gerais e professor catedrático na Universidade de Aveiro. Tem igualmente publicado diversos artigos em revistas nacionais e internacionais, e escreveu um livro sobre teoria analítica da música do século XX. 